THE REPUBLIC OF UGANDA

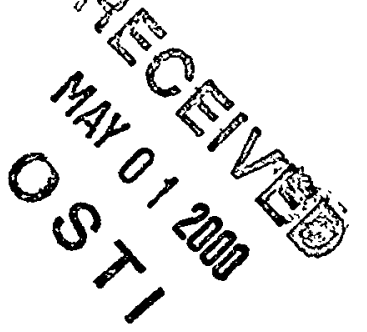

\title{
ASSESSMENT OF VULNERABILITY TO CLIMATE CHANGE
}

\author{
AS WELL AS
}

ADAPTATION AND MITIGATION OPTIONS

(UNITED STATES COUNTRY STUDIES PROGRAMME)

FINAL TECHNICAL REPORT

Ministry of Water, Lands and Environment,

Department of Meteorology,

P.O. Box 7025,

Kampala (Uganda)

Tel: 256-41-251798/233559/255609

Fax: 256-41-251797

E-mail: bapuuli@starcom.co.ug

January, 2000

Kampala 


\section{DISCLAIMER}

This report was prepared as an account of work sponsored by an agency of the United States Government. Neither the United States Government nor any agency thereof, nor any of their employees, make any warranty, express or implied, or assumes any legal liability or responsibility for the accuracy, completeness, or usefulness of any information, apparatus, product, or process disclosed, or represents that its use would not infringe privately owned rights. Reference herein to any specific commercial product, process, or service by trade name, trademark, manufacturer, or otherwise does not necessarily constitute or imply its endorsement, recommendation, or favoring by the United States Government or any agency thereof. The views and opinions of authors expressed herein do not necessarily state or reflect those of the United States Government or any agency thereof. 


\section{DISCLAIMER}

Portions of this document may be illegible in electronic image products. Images are produced from the best available original document. 


\section{TABLE OF CONTENTS}

List of Tables -..-

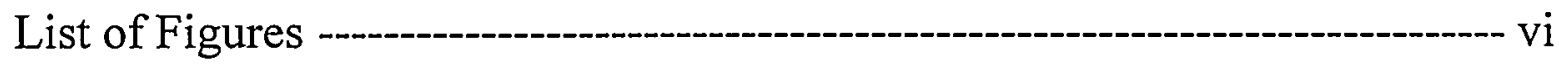

Authors --.--------_- 1

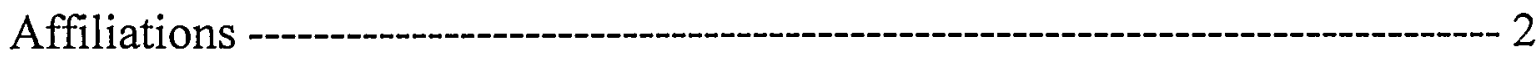

1.0 SUMMARY --_- 3

1.1 Introduction to Climate Change Issues in Uganda --.---..-- 3

1.2 Scenarios used in the V\&A Assessment -

2.0 UGANDA'S V\&A ASSESSMENT FOR THE AGRICULTURE

SECTOR --_-_- 7

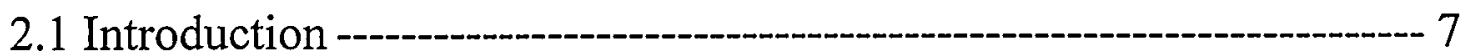

2.2 Methods used for V\&A Assessment-_........- 7

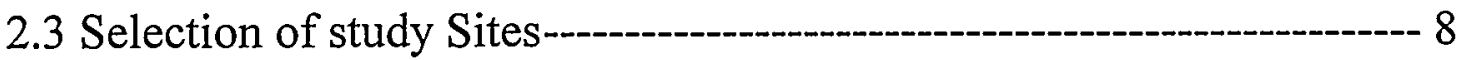

2.4 Methodology for economic Analyses -

2.5 Results of the V\&A Assessment ---_-_- 9

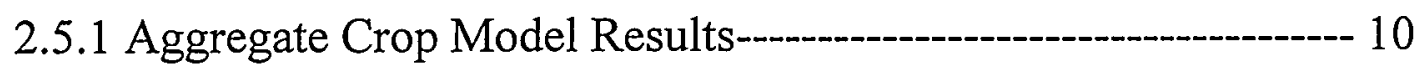

2.5.2 Economic Analyses -...-_- 10

2.6 Adaptation Policies ----------- 12

2.6.1 List of adaptation Policies--_-_- 12

2.6.2 Evaluation of adaptation Alternatives for Crops -------.-_-_--- 12

2.7 Discussions and Conclusions --- 12

3.0 UGANDA'S V\&A ASSESSMENT FOR THE

GRASSLANDS/LIVESTOCK SECTOR -.-_-_-_._- 15

3.1 Introduction ---.-- 15

3.1.1 Production Systems -.--- 15

3.1.2 Grassland (Grazing land)-----..-- 16

3.1.3 Gross Domestic Product (GDP) --_-.- 17

3.2 Methodologies --- 18

3.2.1 Methods used for Vulnerability and Adaptation Assessment --- 18

3.2.2 Plant Species used in the Assessment -.-.-.-.- 18

3.2.3 Animal species (Breeds)--.-- 18

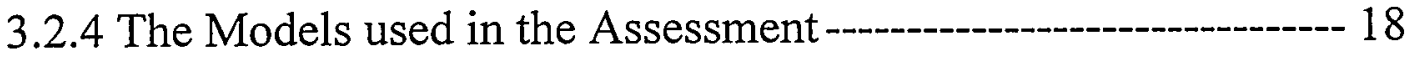

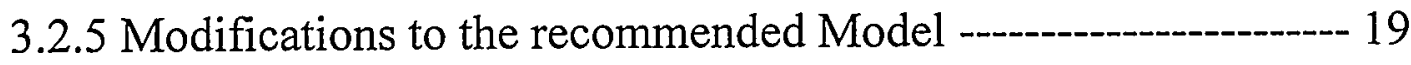

3.2.5.1 Plotting--- 19

3.2.5.2 Forbes --..-- 19

3.2.5.3 Warm and Cool Seasons---_-_- 19

3.2.6 Sources of Weather and Time Series Data---_--_------- 19

3.2.7 Selection of Study Site - 19 
3.2.8 Setting up SPUR2 for the Climate Change Scenarios------------ 22

3.2.8.1 Nominal Run -.-.-- 22

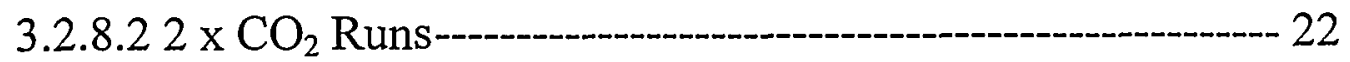

3.2.8.3 GCM Runs -............-...- 22

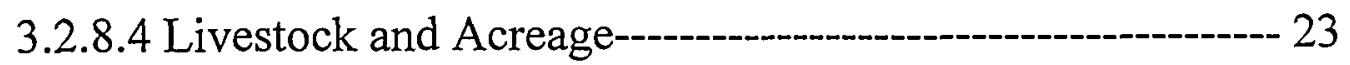

3.3 Results (Diagnosis of the problems of Climate Change and

Variability)--------- 23

3.3.1 Study Site Results by Climate Change scenarios ---.-.-...- 23

3.3.1.1 Temperature and precipitation ------------------------- 23

3.3.1.2 Peak Standing Crop (PSC) --..- 23

3.3.1.3 Soil Organic Matter (SOM) - 23

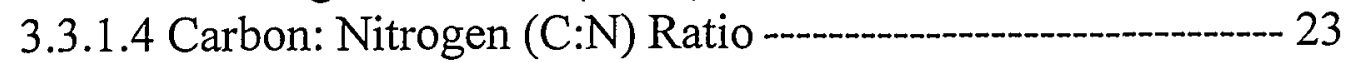

3.4 Possible Adaptation Measures -------------------------------------- 30

3.4.1 Medium Term Responses - - 31

3.4.1.1 By Time-------------------- 31

3.4.1.2 By Level of Action ------------------------------------ 31

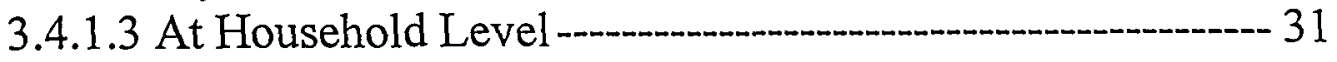

3.4.2 long-term Strategies (Adaptation Options) --------------------- 31

3.4.2.1 Existing Laws -............-- 31

3.4.3 Grazing Management --- 32

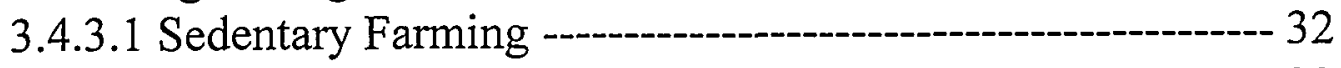

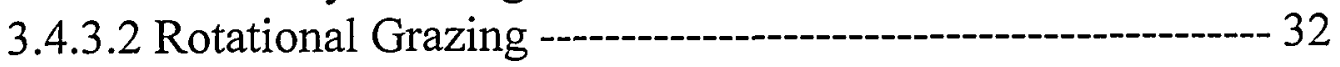

3.4.3.3 Feed Lot -...- 33

3.4.3.4 Carrying Capacity (Stoking Rates)---_---o----------------- 33

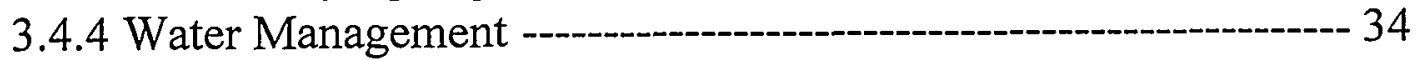

3.4.5 Agroforestry and Integrated Farming -

3.4.6 Animal Breeding -

3.4.6.1 Factors to be considered --- 35

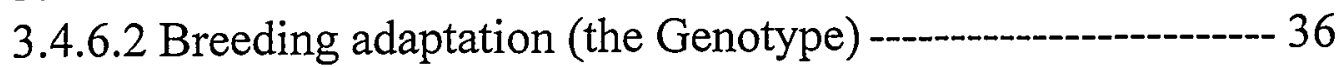

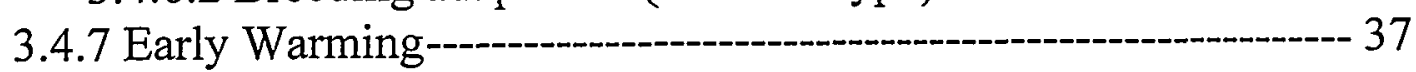

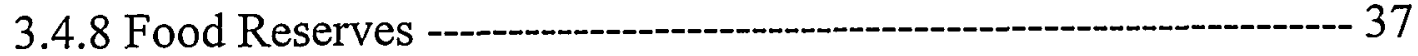

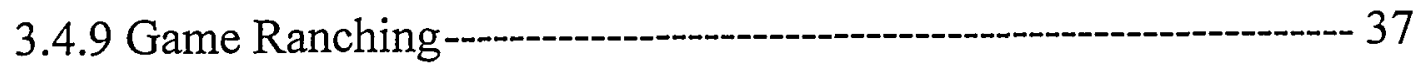

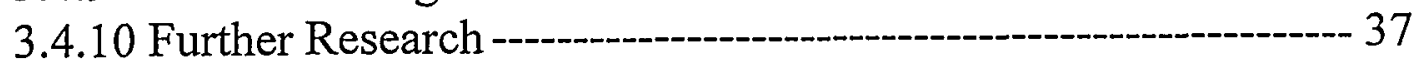

3.5 Discussions and Conclusions-_- 37

3.5.1 Temperature and Precipitation--.-- 37

3.5.2 Peak Standing Crop (PSC) ----_- 37

3.5.3 Soil Organic matter (SOM) ----o- 38

3.5.4 Carbon: Nitrogen (C:N) Ratio -.....- 38 
3.5.5 Nutritive Value of Uganda Grasses -- 38

3.5.6 Conclusions -.-.-.- 39

3.6 References-----------------_-_-_- 41

4.0 UGANDA'S V\&A ASSESSMENT FOR THE FORESTRY SECTOR -- 42

4.1 Methods used for the V\&A Assessment -._-_._- 42

4.1.1 Forest Ecosystem Models used in the Assessment --.--...-...-- 42

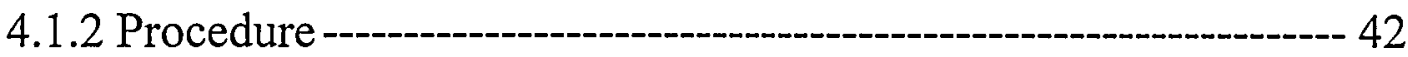

4.1.3 Holdridge Life Model Results by Climate Change Scenario---- 43

4.2 Selection of Study Sites ---

4.3 Results of the V\&A Assessment -....... 45

4.3.1 Holdrige Life Zone Model Results by Climate Change Scenario----.----- 45

4.3.2 Evaluation of Adaptation Polices Using V\&A Assessment Results -----------_-_-_-_-- 47

4.3.3 Forestation-- 47

4.3.4 Forest Protection and conservation --------------------------------- 48

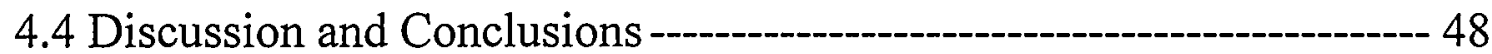

5.0 UGANDA'S V\&A ASSESSMENT FOR THE WATER RESOURCES SECTOR -

5.1 Introduction --

5.2 Methods used for the V\&A Assessment --- 50

5.2.1 Hydrologic and Water resources Methodologies used in the

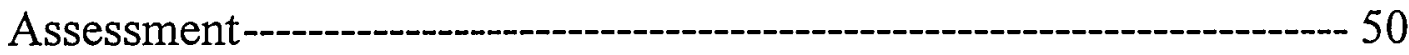

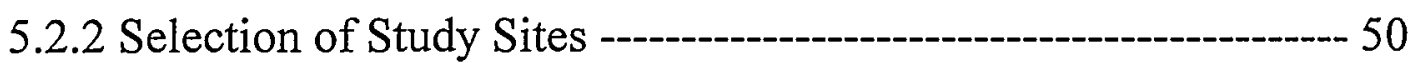

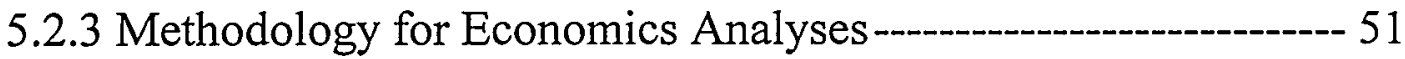

5.3 Adaptation Alternatives Evaluated Using the Methodologies ---_---- 52

5.4 Results of V\&A Assessment--- 52

5.4.1 Results of the Hydrologic Vulnerability Assessment --.-------- 52

5.4.2 Results of Water Resources Supply and Demand Models by

Climate Change Scenarios --- 54

5.5 Evaluation of Adaptation Policies Using V\&A Assessment Results - 56

5.6 Evaluation of Adaptation against Multiple criteria--------------------- 56

5.7 Discussion and Conclusions ---.-- 56

6.0 MITIGATION OPTIONS ASSESSMENT FOR THE ENERGY

SECTOR - -.-_-_-_- 58

6.1 Introduction --_-.-- 58

6.1.1 Geography--.-- 58

6.1.2 Population --_-_- 58

6.1.3 Economic Structure -- 58 


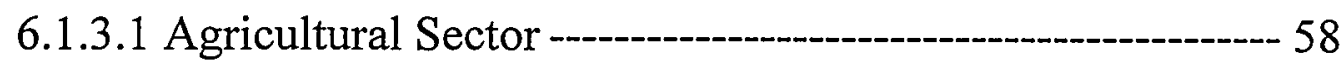

6.1.3.2 Industrial Sector ------o- 58

6.1.4 GHG Mitigation Analysis -.-_-_-_- 59

6.2 Energy Sector Overview - - 59

6.3 Methodology and Data -- 60

6.4 Results - - 62

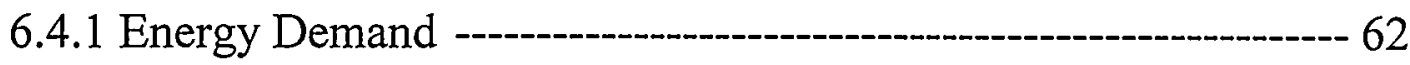

6.4.2 Cost of Emission Abatement-..-- 66

6.4.3 Contribution of Technology Options for GHG Abatement------ 67

6.5 Conclusions and Limitations --_- 67

6.6 References-- 68

7.0 GENERAL CONCLUSIONS AND RECOMMENDATIONS------------ 70 


\section{LIST OF TABLES}

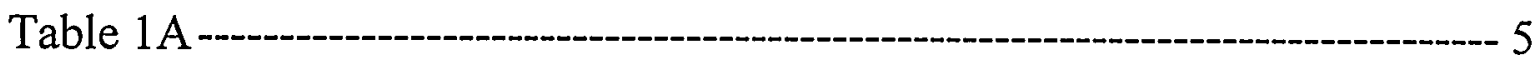

Table 1B -

Table 1C -..-_-_-_- 5

Table 1D -..-_..-_- 5

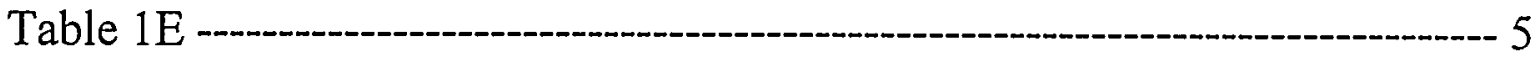

Table $1 F$ -

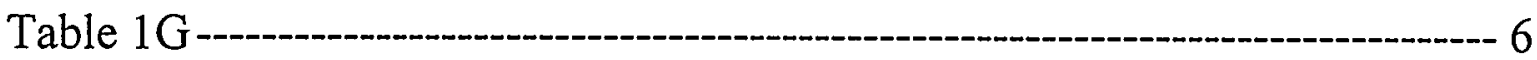

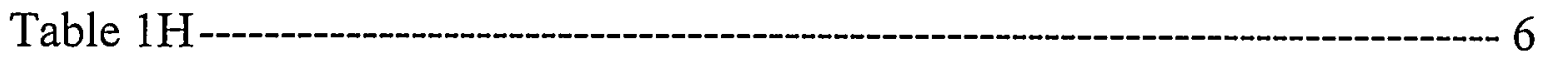

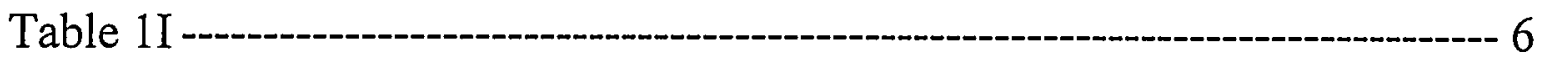

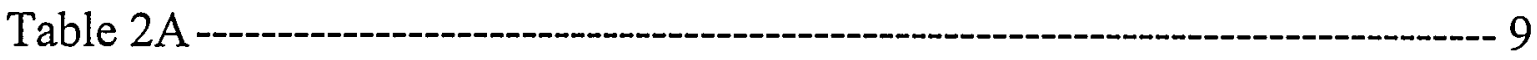

Table 3A --..-- 16

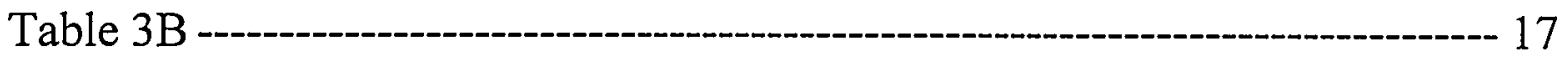

Table 3C/A -- 21

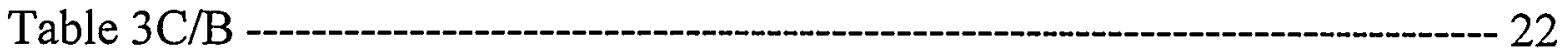

Table 3D -.....-..-- 24

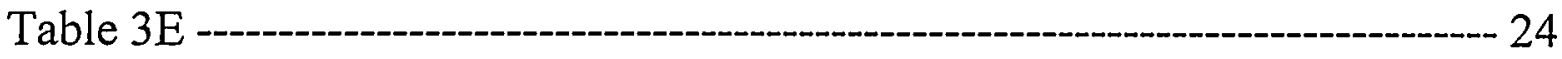

Table 3F - -.-.-.-- 24

Table 3G -......-._- 25

Table 3H--.-- 30

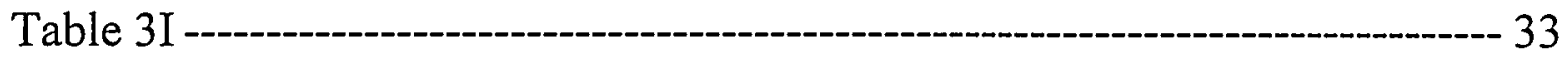

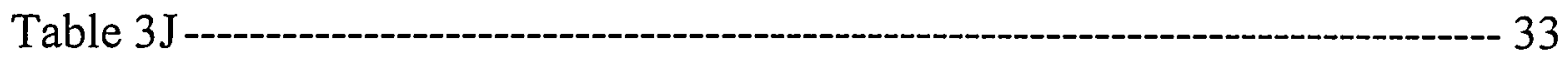

Table 3K ------- 38

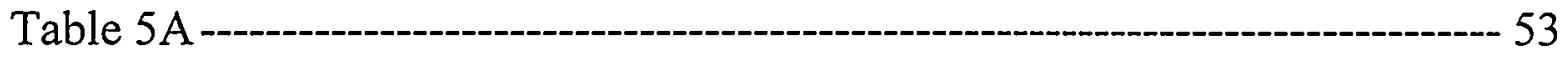

Table 5B.1 - 53

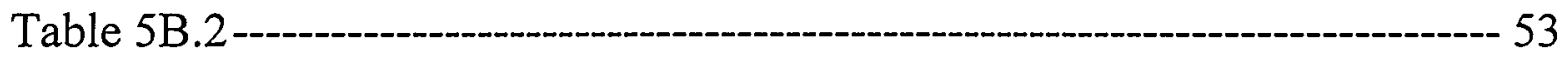

Table 5B.3 ---------_-_._- 54

Table 5B.4---_--- 54

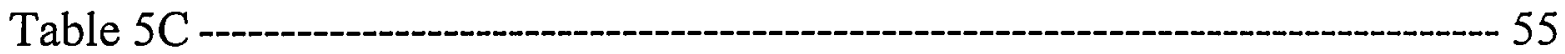

Table 6A --- 62

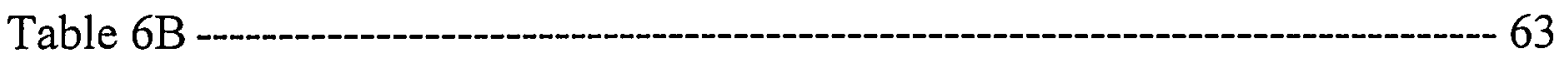

Table 6C -.-...-.-- 63

Table 6D -..-- 64

Table 6E -....-- 64

Table 6F --_-_- 65

Table 6G--..-_- 66 


\section{LIST OF FIGURES}

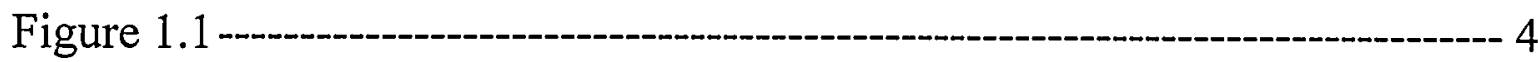

Figure 3.1 ----------- 26

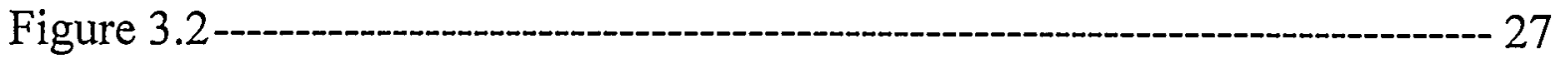

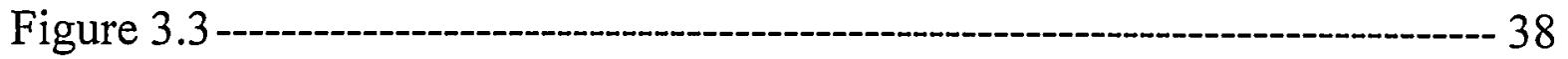

Figure 3.4----------------------.-- 29

Figure 3.5---- 35

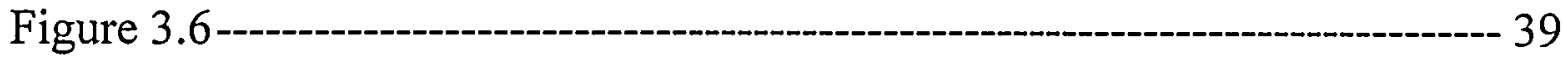

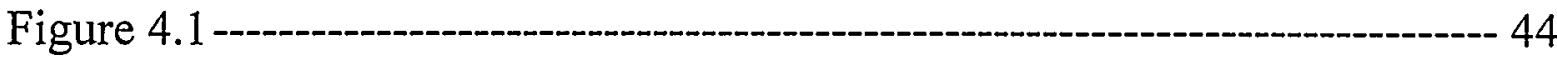

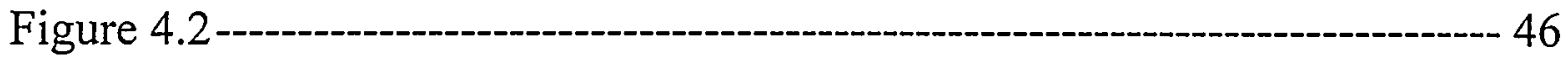


Results of Vulnerability, Adaptation and Mitigation Assessments for Uganda

\section{Authors:}

(1) Project Manager, Mr. Bwango-Apuuli

Commissioner for Meteorology, Department of Meteorology

P.O. Box 7025, Kampala, Uganda.

Mobile No. 077404110

Telephone No. 25641 251798/233559/255609

Fax No. 0025641251797

E-Mail: bapuuli@starcom.co.ug

(2) Assistant Project Manager, Mr. Magezi-Akiiki J.B.

Senior Research Meteorologist

Department of Meteorology,

P.O. Box 7025, Kampala, Uganda,

Mobile No. 077413311

Telephone No. 25641 251798/233559/255609

Fax No. 0025641251797

E-Mail: bapuuli@starcom.co.ug

(3) Introduction and climate Change Scenarios

Mr. Magezi-Akiiki J.B.

Senior Research Meteorologist

Department of Meteorology,

P.O. Box 7025, Kampala, Uganda,

Mobile No. 077413311

Telephone No. 25641 251798/233559/255609

Fax No. 0025641251797

E-Mail: bapuuli@starcom.co.ug

(4) Agricultural Sector,

Mr. Kalule Sewali J.B.

Assistant Commissioner

Department of Crop Production

Ministry of Agriculture, Animal Industry \& Fisheries

P.O. Box 513, Entebbe, Uganda.

Telephone No. 25641 320363/320187 
(5) Rangelands and Livestock Sector,

Dr. C.W. Bunooti,

Assistant Commissioner,

Department of Animal Production and Marketing,

Ministry of Agriculture, Animal Industry \& Fisheries

P.O. Box 513, Entebbe, Uganda.

Telephone No. 25641 321040/320864

Fax No. 25641320428

(6) Forestry Sector,

Mr. Paul Drichi,

Senior Forestry Officer,

Department of Forestry,

P.O. Box 1613, Kampala, Uganda,

Telephone No. 25641251779

Fax No. 25641251778

(7) Energy Mitigation Assessment,

(i) Mr. Hatanga S. (RIP)

Department of Energy,

P.O. Box 7270 ,

Kampala, Uganda.

Telephone No. $25641349342 / 257863$

(ii) Ms. Cissy Mbabazi,

Ministry of Natural Resources,

P.O. Box 7270 ,

Kampala, Uganda.

\section{Affiliations:}

(i) Department of Meteorology

Ministry of water, Lands and environment,

(ii) Ministry of Agriculture, Animal Industry and Fisheries

(iii) Department of Forestry

Ministry of water, Lands and Environment.

(iv) Directorate of water Resources

Ministry of Water, Lands and Environment

(v) Department of Energy

Ministry of Energy and Mineral Development

(vi) Ministry of Finance, Planning and Economic Development 


\subsection{SUMMARY:}

\subsection{Introduction to Climate Change Issues in Uganda}

Uganda spans almost $236,000 \mathrm{~km}^{2}$ of which about $15.3 \%$ is open water, $2 \%$ swamps and $26.2 \%$ forest. Uganda's population is about 20 million. There are in most areas of Uganda quite well marked wet and dry seasons. The rain seasons in most parts of the country begin shortly after the hottest time of the year and are related, with a short time lag, to the main air current, both on the surface and in the upper atmosphere. On the surface these currents are generally known as the Southeast and Northeast Monsoons and these winds tend to move with the sun. Uganda (particularly the western districts) also receives rain from a westerly airstream coming from the directions of the Congo. Climate is considered as one of the major resources and rainfed agriculture is the mainstay of the economy accounting for about $50 \%$ of GDP as of 1996 and over $95 \%$ of the merchandise exports and therefore the growth of the agricultural sector greatly determines the performance of the economy. It provides employment for about $80 \%$ of population and is the economic base for much of the manufacturing and service industries. Negative climate change would therefore adversely affect the economy. National Policies must therefore be evolved to tackle the problem of global warning associated with greenhouse gas emissions. The key impacts of climate change are likely to strongly affect the following sectors:
a) Agriculture;
b) Forestry;
c) Natural Ecosystems and Wildlife;
d) Water resources;
e) Fisheries;
f) Human Settlements
g) Energy;
h) Transport and Industry;
i) Human Health; and
j) Air Quality.

The main objective of this study was to assess the countries vulnerability to climate change and evaluate the possible adaptation and mitigation options to climate change. Although all the sectors listed above are considered important, it was not possible to cover all of them during this study party due to financial constraints. Only the sectors of water resources, forestry, crops as well as livestock and rangelands were therefore covered in the study. Energy and non-energy issues were also looked at in assessing the possible mitigation options.

It funds become available in future, assessments in the fields of fisheries, human health and wildife will be carried out. 


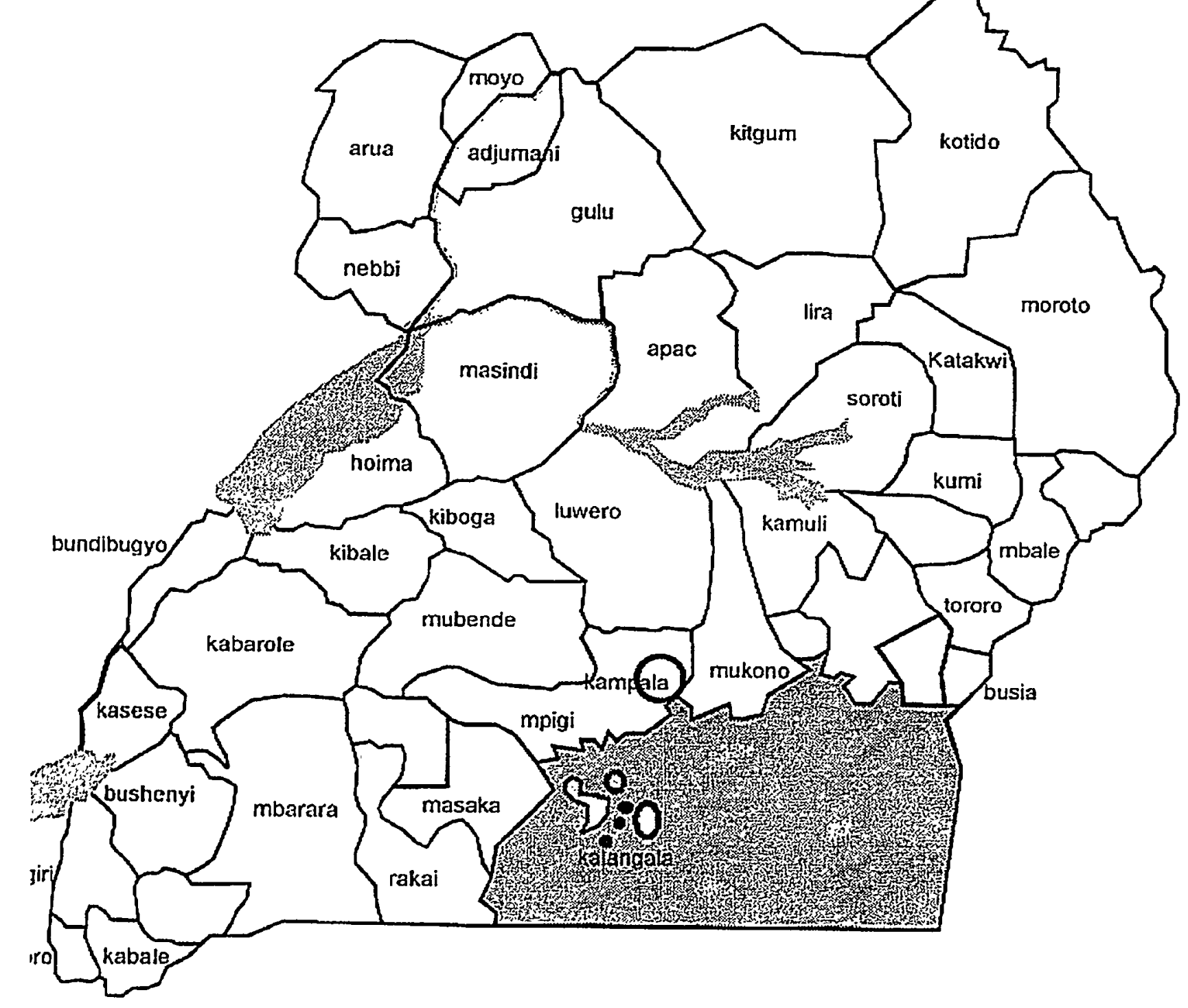

FIGURE 1.1 Map of Uganda 


\subsection{Scenarios used in the V\&A Assessment}

Table 1.A_Adjustment Statistics for the Difference between $2 \mathrm{XCO}_{2}$ and Current $\left(1 \mathrm{XCO}_{2}\right)$ Generated by the CCCM General Circulation Model

\begin{tabular}{|l|l|l|l|l|l|l|l|l|l|l|l|l|l||}
\hline ARUA & Jan & Feb & Mar & Apr & May & Jun & Jul & Aug & Sep & Oct & Nov & Dec & Annual \\
\hline $\begin{array}{l}\text { Temperature } \\
\text { (C) })\end{array}$ & 3.15 & 3.31 & 2.30 & 2.35 & 2.10 & 2.12 & 2.16 & 2.35 & 2.50 & 2.17 & 2.78 & 2.92 & 2.52 \\
$\begin{array}{l}\text { Precipitation } \\
\text { Ratio }\end{array}$ & 1.15 & 1.52 & 0.92 & 1.18 & 0.92 & 0.75 & 0.62 & 0.99 & 0.84 & 0.29 & 0.99 & 1.02 & 0.94 \\
\hline
\end{tabular}

Table 1.B_Adjustment Statistics for the Difference between $2 \mathrm{XCO}_{2}$ and Current $\left(\mathrm{XCO}_{2}\right)$ Generated by the CCCM General Circulation Model

\begin{tabular}{|l|l|l|l|l|l|l|l|l|l|l|l|l|l|}
\hline LIRA & Jan & Feb & Mar & Apr & May & Jun & Jul & Aug & Sep & Oct & Nov & Dec & Annual \\
\hline \hline $\begin{array}{l}\text { Temperature } \\
\text { ( - })\end{array}$ & 2.75 & 2.63 & 1.97 & 2.37 & 2.20 & 2.19 & 2.02 & 2.16 & 2.38 & 2.40 & 2.69 & 2.71 & 2.37 \\
$\begin{array}{l}\text { Precipitation } \\
\text { Ratio }\end{array}$ & 1.14 & 1.41 & 0.94 & 1.42 & 0.90 & 0.89 & 0.82 & 0.97 & 0.93 & 0.99 & 1.16 & 0.95 & 0.996 \\
\hline
\end{tabular}

Table 1.C_Adjustment Statistics for the Difference between $2 \mathrm{XCO}_{2}$ and Current $\left(1 \mathrm{XCO}_{2}\right)$ Generated by the CCCM General Circulation Model

\begin{tabular}{|c|c|c|c|c|c|c|c|c|c|c|c|c|c|}
\hline ENTEBBE & Jan & Feb & Mar & Apr & May & Jun & Jul & Aug & Sep & Oct & Nov & Dec & Annual \\
\hline $\begin{array}{l}\text { Temperature } \\
(\mathrm{c})\end{array}$ & 2.56 & 2.41 & 2.11 & 2.26 & 2.27 & 2.12 & 2.02 & 2.23 & 2.40 & 2.38 & 2.47 & 2.51 & 2.31 \\
\hline $\begin{array}{l}\text { Precipitation } \\
\text { Ratio }\end{array}$ & 1.09 & 1.27 & 0.93 & 1.08 & 0.87 & 0.72 & 0.65 & 0.85 & 0.86 & 1.02 & 1.07 & 1.04 & 0.976 \\
\hline
\end{tabular}

Table 1.D_Adjustment Statistics for the Difference between $2 \mathrm{XCO}_{2}$ and Current $\left(1 \mathrm{XCO}_{2}\right)$ Generated by the GFD3 General Circulation Model

\begin{tabular}{|l|l|l|l|l|l|l|l|l|l|l|l|l|l||}
\hline ARUA & Jan & Feb & Mar & Apr & May & Jun & Jul & Aug & Sep & Oct & Nov & Dec & Annual \\
\hline $\begin{array}{l}\text { Temperature } \\
\text { C: }\end{array}$ & 2.75 & 2.50 & 1.45 & 1.92 & 2.31 & 2.79 & 3.21 & 2.70 & 2.23 & 2.39 & 2.37 & 2.27 & 2.41 \\
$\begin{array}{l}\text { Precipitation } \\
\text { Ratio }\end{array}$ & 0.93 & 1.21 & 1.18 & 1.02 & 1.16 & 1.21 & 1.01 & 1.16 & 1.02 & 1.06 & 1.30 & 1.06 & 1.126 \\
\hline
\end{tabular}

Table 1.E Adjustment Statistics for the Difference between $2 \mathrm{XCO}_{2}$ and Current $\left(1 \mathrm{XCO}_{2}\right)$ Generated by the GFD3 General Circulation Model

\begin{tabular}{|l|l|l|l|l|l|l|l|l|l|l|l|l|l||}
\hline LIRA & Jan & Feb & Mar & Apr & May & Jun & Jul & Aug & Sep & Oct & Nov & Dec & Annual \\
\hline $\begin{array}{l}\text { Temperature } \\
\text { (Cri) }\end{array}$ & 2.51 & 2.52 & 1.87 & 2.00 & 2.19 & 2.24 & 3.38 & 3.01 & 2.41 & 2.49 & 2.73 & 2.53 & 2.53 \\
$\begin{array}{l}\text { Precipitation } \\
\text { Ratio }\end{array}$ & 1.07 & 1.15 & 1.40 & 1.04 & 1.22 & 1.15 & 1.15 & 1.17 & 1.11 & 1.28 & 1.24 & 1.19 & 1.17 \\
\hline
\end{tabular}


Table 1.F Adjustment Statistics for the Difference between $2 \mathrm{XCO}_{2}$ and Current $\left(1 \mathrm{XCO}_{2}\right)$

Generated by the GFD3 General Circulation Model

\begin{tabular}{|c|c|c|c|c|c|c|c|c|c|c|c|c|c|}
\hline ENTEBBE & Jan & Feb & Mar & Apr & May & Jun & Jul & Aug & Sep & Oct & Nov & Dec & Annual \\
\hline $\begin{array}{l}\text { Temperature } \\
\mathrm{LC} \text { C }\end{array}$ & 2.51 & 2.61 & 2.28 & 2.18 & 2.48 & 2.98 & 3.58 & 3.37 & 2.58 & 2.57 & 2.76 & 2.57 & 2.71 \\
\hline $\begin{array}{l}\text { Precipitation } \\
\text { Ratio }\end{array}$ & 1.13 & 1.00 & 1.48 & 1.02 & 1.10 & 1.07 & 1.26 & 1.09 & 1.24 & 1.19 & 1.18 & 1.23 & 1.16 \\
\hline
\end{tabular}

Table 1.G_Adjustment Statistics for the Difference between $2 \mathrm{XCO}_{2}$ and Current $\left(\mathrm{XCO}_{2}\right)$

Generated by the UK89 General Circulation Model

\begin{tabular}{|l|l|l|l|l|l|l|l|l|l|l|l|l|l|}
\hline ARUA & Jan & Feb & Mar & Apr & May & Jun & Jul & Aug & Sep & Oct & Nov & Dec & Annual \\
\hline $\begin{array}{l}\text { Temperature } \\
\text { (C.) }\end{array}$ & 1.39 & 3.53 & 4.02 & 4.22 & 3.18 & 3.26 & 3.35 & 4.69 & 4.49 & 3.61 & 2.75 & 2.14 & 3.39 \\
$\begin{array}{l}\text { Precipitation } \\
\text { Ratio }\end{array}$ & 0.80 & 1.03 & 0.55 & 1.09 & 1.25 & 1.47 & 0.81 & 0.63 & 1.04 & 1.42 & 1.56 & 1.79 & 1.12 \\
\hline \hline
\end{tabular}

Table 1.HAdjustment Statistics for the Difference between $2 \mathrm{XCO}_{2}$ and Current $\left(1 \mathrm{XCO}_{2}\right)$

Generated by the UK89 General Circulation Model

\begin{tabular}{|l|l|l|l|l|l|l|l|l|l|l|l|l|l||}
\hline LIRA & Jan & Feb & Mar & Apr & May & Jun & Jul & Aug & Sep & Oct & Nov & Dec & Annual \\
\hline $\begin{array}{l}\text { Temperature } \\
\left(C^{-}\right)\end{array}$ & 1.39 & 3.93 & 4.69 & 4.19 & 3.65 & 3.13 & 3.48 & 4.08 & 3.82 & 3.36 & 2.82 & 2.62 & 3.48 \\
$\begin{array}{l}\text { Precipitation } \\
\text { Ratio }\end{array}$ & 0.53 & 0.77 & 0.51 & 1.06 & 1.28 & 1.64 & 0.85 & 0.86 & 1.30 & 1.42 & 1.46 & 1.49 & 1.09 \\
\hline
\end{tabular}

Table 1.I_Adjustment Statistics for the Difference between $2 \mathrm{XCO}_{2}$ and Current $\left(1 \mathrm{XCO}_{2}\right)$ Generated by the UK89 General Circulation Model

\begin{tabular}{|c|c|c|c|c|c|c|c|c|c|c|c|c|c|}
\hline ENTEBBE & Jan & Feb & Mar & Apr & May & Jun & Jul & Aug & Sep & Oct & Nov & Dec & Annual \\
\hline $\begin{array}{l}\text { Temperature } \\
\left(\mathrm{C}^{-}\right)\end{array}$ & 2.36 & 4.32 & 4.70 & 3.78 & 2.96 & 3.02 & 4.03 & 4.06 & 3.55 & 3.30 & 2.87 & 2.76 & 3.48 \\
\hline $\begin{array}{l}\text { Precipitation } \\
\text { Ratio }\end{array}$ & 0.70 & 0.82 & 0.75 & 1.20 & 1.57 & 1.51 & 0.80 & 1.00 & 1.32 & 1.20 & 1.26 & 1.37 & 1.13 \\
\hline
\end{tabular}




\subsection{UGANDA'S V\&A ASSESSMENT FOR THE AGRICULTURE SECTOR}

\subsection{Introduction}

The model results indicate that the environmental and stress factors have been greatly reduced from the actual figures, i.e. temperature maximum, temperature minimum and solar radar.

The resulting effect of this reduced environmental factors is that crop growth was delayed at all phases. The maize yield obtained at different planting dates (treatments) is the same and very low due to slowed grain filing. There is therefore no significant difference between yields and the other growth and development variables also show no difference across treatments.

\subsection{Methods Used for the V\&A Assessment}

\section{Crop Models Used in the Assessment}

Maize is a major food grain in Uganda and has been analyzed using CERES - Maize model. CERES Maize model developed by the United States Department of Agriculture, Agricultural Research Service (USDA - ARS) has been incorporated in the Decision Support System for Agrometeorology Transfer (DSSAT). DSSAT is a microcomputer based shell which includes a Data Base Management System (DBMST), crop model and application programs. (IBSNAT 1989, Jones et al, 1990) DSSAT was developed by the International Benchmark sites Network for Agrometeorology Transfer Project (IBSNAT).

CERES - Maize model is designed to simulate the effect of cultivar, planting density, weather, soil moisture and nitrogen on crop growth, development and yield.

Models for other food crops within DSSAT include phaseolus bean (dry bean), rice, sorghum, millet, barley, wheat, soybean, peanut, cassava, taro and potatoes. These twelve food crops were divided into three groups on the basis of their similarity structure. The name of model families are CERES for grain crops, SoyGRO for legumes and SUBSTOR for storage plants (Hunkir M 1994). All of the models use the same Minimum Data Set (MDS) which defines the required input variables to operate the models (IBSANAT 1990).

These MDS include daily temperatures, precipitation and solar radiation. Cultural practices include planting date, density and cultivar selection. The application section of DSSAT contains a strategy and risk analysis section. This allows for long term simulations, using historical or generated weather data, to analyze management practices, such as planting date, cultivar selection and irrigation. 


\subsection{Selection of Study Sites}

Namulonge Agricultural and Animal Research Institute (NARRI) was selected for the study:

Latitude $\quad 00-31 \mathrm{~N}$

Longitude $032-38 \mathrm{E}$

Elevation $11288 \mathrm{~m} \mathrm{MSL}$

It is a major food production area located in Central Uganda - Mpigi District, where, unlike most parts of Uganda, agrometeorological data is compiled.

Uganda is a unified variety in terms of ecology. Just using the rainfall distribution criteria, Uganda's regions range from semi-arid with short rain seasons of 1 - 2 months, through long unimodel zones of $5-6$ months, to bimodal regions of two rain peaks. Montane and Lake Victoria regions display less defined patterns with rainfall occurring throughout the year with a bimodal regime. This ecological definition is however based on past 30 years, however, pronounced rainfall pattern variability has been a common phenomenon in all the ecological zones. The most affected have been the semi-arid zones where total rainfall failure is registered and the bimodal areas where uncertain start and early break of the rain season greatly affect the season length. The planting date experiment is a good hypothesis to test crop performance using conventional farmers planting dates as they try to track the uncertain onset of the season.

Namulonge is representative of the bimodal zone. Seasonal variability include: late start of the season, early break of the rains, which two conditions, cause shorter favourable crop growing season. The severity of the dry spells is however taking a more disastrous form. Short spells of $5-7$ days are creating stress conditions to crops evidenced by leaf dropping (turner loss) pale canopy and early leaf senescence.

Yield losses due to changing rainfall patterns have been unprecedented and no effort to assess the impact of these phenomena on crops has been made.

As a remedial strategy, manipulating the planting dates and introduction of small scale irrigation to compensate for rain season failure offer an alternative. The model's capacity to integrate the climate change with crop performance to give an adaptation package is without doubt an invaluable tool in the crop weather studies and its introduction in Uganda has been long overdue.

Namulonge has adequate data sets though not yet computerized; and for the weather data emphasis has been put on the most recent past, i.e. from 1964 to 1994 (30 years). 


\subsection{Methodology for Economic Analyses}

Most testing was done on experimental exercise. The experiment was that of planting dates as the treatments on maize Longe - 1 cultivar. Its growth cycle is 120 days from germination to maturity. This cultivar is a recent release in Uganda and it is an improved variety of Kawanda composites whose growth cycle covers $140-160$ days.

The maize Longe - 1 variety has a potential yield of $4,000-6,000 \mathrm{~kg} / \mathrm{Ha}$ and was developed with some consideration of shortening rain seasons. Namulonge is in the bimodal rainfall region with two rain peaks. The first season starts in March and ends between May and June. Statistical evidence here reveals that the start of the first season varies from 15 February to 27 March. The end of the season also varies from 21 May to 28 June. This makes the season length vary from 65 to 101 days. There is a great uncertainty at the start and end of the season, only the peak periods between April and May have remained a bit stable. The second season starts in September and ends in December. The hypothesis of manipulating planting dates with some irrigation at early stages of crop establishment is to align the critical states of: end of juvenile, floral/silking and grain filling to this period when moisture availability is a bit certain. That is why the choice of planting dates range from 19 February to 30 March.

\subsection{Results of the V\&A Assessment}

The results show that weather, soil parameters, cultivar genotype co-efficient and the designed experiment (hypothetical) data was properly placed in the appropriate directories as can be read from the summary of soil and genetic input parameters.

From the results, the weather data was profoundly reduced when put in NCAR directory. From the environmental and stress factors section the $T$ max read is

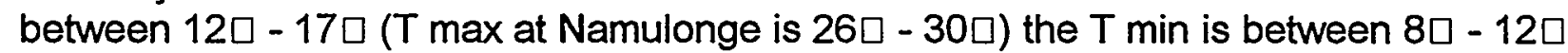
( $T$ min at Namulonge is $14 \square-17 \square$. Solar radiation fell to $9 \mathrm{MJ} / \mathrm{M}$ from floral initiation to $5 \mathrm{MJ} / \mathrm{M}$ at grain filling. This is not actual data for Namulonge. The yield obtained at all runs, i.e. treatments are the same and very low $29 \mathrm{~kg} / \mathrm{Ha}$ and the crop age at maturity is 310 days instead of the normal 120 days. Growing season precipitation and Evaportranspiration are too high (Table 2A).

TABLE 2A: DSSAT MODEL FARM LEVEL RESULTS BY CLIMATE CHANGE SCENARIO AND ADAPTATION ALTERNATIVE FOR MAIZE

\begin{tabular}{|l|l|l|l|l||}
\hline YIELDS & SEASON LENGTH & \multicolumn{1}{|c|}{$\begin{array}{c}\text { GROWING } \\
\text { SEASON } \\
\text { PRECIPITATION }\end{array}$} & $\begin{array}{c}\text { GROWING } \\
\text { SEASON } \\
\text { EVAPOTRANSPIR } \\
\text { ATION }\end{array}$ & $\begin{array}{c}\text { WATER USED } \\
\text { FOR IRRIGATION }\end{array}$ \\
\hline$T / \mathrm{Ha})$ & (d) & $(\mathrm{mm})$ & $(\mathrm{mm})$ & $(\mathrm{mm})$ \\
\hline 029 & 310 & 11001 & 3806 & 412 \\
\hline
\end{tabular}




\subsubsection{Aggregate Crop Model Results}

Site specific results of the model were much exaggerated hence aggregation to regional areas was not simulated. However, the Table below gives production of maize in the production zones of Uganda.

\begin{tabular}{||l|l|c|c||}
\hline REGION & \multicolumn{1}{|c|}{ FARMING SYSTEM } & $\begin{array}{c}\text { MANAGEMENT } \\
\text { PRACTICE (MAIZE) }\end{array}$ & $\begin{array}{c}\text { PERCENTAGE OF TOTAL } \\
\text { PRODUCTION (1996) }\end{array}$ \\
\hline Northern & $\begin{array}{l}\text { Annual cropping and cattle in } \\
\text { Northern zone and West Nile } \\
\text { Zone }\end{array}$ & Medium input commercial & 29 \\
\hline Western & $\begin{array}{l}\text { Western Banana Coffee Cattle } \\
\text { System + pastoral and annual } \\
\text { crops }\end{array}$ & Medium input commercial & 19 \\
\hline $\begin{array}{l}\text { South } \\
\text { Westem }\end{array}$ & Montana system & Subsistence & 5 \\
\hline Central & $\begin{array}{l}\text { Medium altitude intensive } \\
\text { banana coffee system + some } \\
\text { annual crops }\end{array}$ & Subsistence & 37 \\
\hline Eastern & $\begin{array}{l}\text { Banana millet cotton system } \\
\text { annual cropping and cattle } \\
\text { Teso system + montane } \\
\text { system }\end{array}$ & High input commercial & \\
\hline North Eastem & $\begin{array}{l}\text { Pastoral and some annual crop } \\
\text { system }\end{array}$ & Subsistence & 2 \\
\hline
\end{tabular}

\subsubsection{Economic Analyses}

Agriculture is the backbone of Uganda's economy. In 1996 agriculture contributed $48.4 \%$ of the GDP. The GDP growth rate is $5 \%$ and mainly contributed by small scale farmers with an average household farming area of 2.5 hectares.

The per capita GDP growth rate was 2.1\% in 1996 (Statistical Abstract 1997 Ministry of Planning and Economic Development).

Many of the food crops have in recent years joined the export market, e.g. maize, simsim, beans, soyabeans, fruits and vegetables.

Export crops include coffee, cotton, tea and tobacco. 
The Table below shows the export value of these crops.

UGANDA CROP EXPORT VALUE

\begin{tabular}{|l|c|}
\hline TRADITIONAL EXPORT CROPS & EXPORT VALUE (BY TONNE) (US\$ 000) \\
\hline Coffee & 1.42 \\
\hline Cotton & 1.57 \\
\hline Tea & 1.16 \\
\hline Tobacco & 2.37 \\
\hline
\end{tabular}

\section{Non-Traditional Export Crops}

\begin{tabular}{||l|l||}
\hline CROP & EXPORT VALUE \\
\hline Maize & 0.2 \\
\hline Beans & 0.39 \\
\hline Sesame seeds & 0.64 \\
\hline Soya beans & 0.75 \\
\hline Cocoa beans & 0.97 \\
\hline Vanilla & $0.05($ per $\mathrm{kg})$ \\
\hline Fruits & 1.35 \\
\hline Groundnuts & 0.18 \\
\hline Bananas & 0.34 \\
\hline Roses and cut flower & $0.0056($ per $\mathrm{kg})$ \\
\hline Ginger & 0.49 \\
\hline Source: (Statistical abstract 1997) & \\
\hline
\end{tabular}

Cost Benefit Analysis of Various Crop Enterprises have been carried out and the benefit cost rate are as follows:

\begin{tabular}{|c|c|c|c|c|c||}
\hline CROP & MAIZE & BEANS & BANANAS & COFFEE & $\begin{array}{c}\text { COFFEE } \\
\text { (CLONAL) }\end{array}$ \\
\hline BENEFITS/COST RATIO & 0.54 & 0.48 & 2.1 & 0.98 & 1.4 \\
\hline
\end{tabular}

Optimal use of family labour on small-scale farms is very much encouraged. 


\subsection{Adaptation Policies}

\subsubsection{List of possible adaptation policies}

It is now recognized that the planet is expecting some climate change and that Uganda is no exception as exemplified by the recurrent changing pattern of rainfall followed by famine. Eradication of poverty from the population is top priority of Uganda through modernization of agriculture.

A modern agriculture is characterized by the following:

(a) Shift from subsistence to commercial agriculture to respond to market opportunities.

(b) Shift from low income to high income enterprises.

(c) Shift from low to high yielding technologies (irrigation, genetic engineering, etc.).

(d) Sustainable utilization of natural resources.

2.6.2. Evaluation of Adaptation Alternatives for crops

\begin{tabular}{||l|l|l|l|l||}
\hline $\begin{array}{l}\text { STRATEGY } \\
\text { NAME }\end{array}$ & $\begin{array}{l}\text { STRATEGY } \\
\text { TYPE }\end{array}$ & $\begin{array}{l}\text { PRACTICE } \\
\text { CHANGE }\end{array}$ & $\begin{array}{l}\text { GOVERNMENT } \\
\text { ACTION }\end{array}$ & $\begin{array}{l}\text { OTHER } \\
\text { POLICIES }\end{array}$ \\
\hline Farm Inputs & Procurement & $\begin{array}{l}\text { Train rural } \\
\text { stockiest }\end{array}$ & $\begin{array}{l}\text { Develop rural } \\
\text { distribution } \\
\text { network }\end{array}$ & Privatization \\
\hline $\begin{array}{l}\text { Farm land use } \\
\text { Aggregation }\end{array}$ & $\begin{array}{l}\text { Sensitization } \\
\text { and training }\end{array}$ & $\begin{array}{l}\text { Small farming } \\
\text { as a business }\end{array}$ & $\begin{array}{l}\text { Promote rural } \\
\text { credit schemes }\end{array}$ & Modernization \\
\hline Cultivars & $\begin{array}{l}\text { Drought } \\
\text { Resistance }\end{array}$ & $\begin{array}{l}\text { Genetic } \\
\text { Engineering }\end{array}$ & $\begin{array}{l}\text { Promote } \\
\text { Research }\end{array}$ & $\begin{array}{l}\text { Research Farmer } \\
\text { extension } \\
\text { linkages }\end{array}$ \\
\hline Technology & $\begin{array}{l}\text { Develop } \\
\text { appropriate } \\
\text { technology }\end{array}$ & $\begin{array}{l}\text { Specialized } \\
\text { advisory } \\
\text { services }\end{array}$ & Training & Modernization \\
\hline
\end{tabular}

\subsection{Discussion and Conclusions}

There is no significant difference between the yields and the other growth and development variables also show no difference across treatments. We expected some difference in yield especially between 19 February planting and 31 March with February having greater output than March. The former planting data aligns the peak 
rainfall period to the critical stages than the later. With the multi-year simulation for climate change crop impact, the climate change models CCCM, GFD3, etc. the program run all over the years but giving results as low rainfall and high temp and solar radiation.

\section{(i) Crop Vulnerability to Climate Change in Uganda}

In Uganda, the diversity in ecological zones make crop vulnerability to climate change manifest itself differently in each zone. In the bimodal regions (Namulonge), seasonal uncertainty especially in the length of the favourable crop-growing period (when precipitation exceeds evapotransipiration) is experienced. This undoubtedly after crop yield especially augmented by erroneous planting dates.

In the Montana zones of Kabale (South West) and Kapchorwa (east) temperature changes are setting new atmospheric evaportranspiration demands resulting in short dry spells expecting great stress on crop growth and development. In the low plainly zones of the unmodal pattern (north northeast), the water balance and ground water are affecting farming systems.

\section{(ii) Adaptation Options}

Manipulating the planting dates with associated agronomic practices of dry planting, supplementary irrigation by encouraging small-scale water shed management practices such as harvesting run-off during the peak rainfall period.

In the long term changes in the farming systems and development of appropriate cultivars by agronomists and breeders can assist in adjusting crop growth cycles to fit in the shortening rainfall periods.

\section{(iii) Use of the DSSAT Model}

The model allows the investigator to manipulate the management alternative to give various biophysical outputs of crop growth. It can simulate results for a single season, a year and multiple years to cater for climate change conditions basing on a minimum weather data set of 30 years. Statistical results can be generated to allow studies of both mean and variance changes in output variables. Outputs can be in form of printed files, graphs or tables. Economic analyses can also be conducted to give returns for the different technology/management options used.

Ideally 30 years are adequate to characterize the climatic variability patterns. The weather variables needed include: solar radiation, temperature both maximum and minimum and precipitation. Crop management information, for example, spacing, irrigation scheduling, plant density, etc. Crop genotype characteristics like time period to flowering, seed weight, degree days to 
maturity, etc. Lastly, soil information for example texture, colour, depth (stoneless zone) $\mathrm{pH}$, water holding capacity, cation exchange, etc.

These data sets are collected at the representative sites and work as input files for the model. The use of the model in Uganda, however, requires more manipulation to march the local conditions modification.

Models for major crops in Uganda need to be developed, e.g. banana is a major staple crop and now emerging as one of the non-traditional export crops. Coffee is a major traditional export crop for Uganda. 


\subsection{UGANDA'S V\&A ASSESSMENT FOR THE GRASSLANDS/LIVESTOCK SECTOR}

\subsubsection{Introduction}

We in Uganda recognize that the increasing concentration of atmospheric anthropogenic gases especially carbon dioxide will cause a change in global temperatures and rainfall.

It has been projected that there will be great increase in temperature and an overall slight increase in precipitation. The result will be drier soils, warming of the atmosphere, negative effects on plants and animal life (location and composition of the various plants and animals in the natural environment depend - to a great extent on climate) which will lead to adverse economic and social problems to the human race.

Notably climate change and variability here in Uganda is expected to affect, quite negatively, the productivity of our grasslands and livestock especially along our traditional "cattle grazing corridor on which rangelands sizeable population of Uganda people ( 7 million, $41 \%$ of Uganda) and livestock (3 million cattle, $60 \%$ of Uganda) depend. Livestock in Uganda mainly comprises of the following species and their total numbers stood as in the brackets by the 31 st December 1995; cattle $(5,499,288)$, goats $(3,703,704)$, sheep $(1,299,405)$, pigs $(1,070,266)$ and poultry $(19,261,456)$.

This study has therefore been initiated to assess among other effects, the impact of the climate change on grasslands and livestock production in this corridor and potential adaptation responses.

\subsubsection{Production Systems}

Livestock (especially cattle) production systems in Uganda can be broadly divided into three categories:
A) Extensive Systems;
B) Semi-Intensive Systems;
C) Intensive Systems

These three can be further sub-divided according to stage of commercialization as follows:

\section{A) Extensive Systems}

- Subsistence - Pastoral system mainly nomadic and or transhumance.

- Semi-Commercial - Agro-pastoral system which is sometimes referred to as communal grazing.

- Entirely-commercial - ranching system (enclosed grazing) 


\section{B) Semi-Intensive Systems}

- Semi-commercial - sedentary crop agriculture with cattle production.

- Entirely commercial - agro-pastoral system

C) Intensive System

- Rotational Cattle/Forage crop production.

- Integrated Cattle perennial crop production.

- Feedlot (zero-grazing) cattle production system.

Over $90 \%$ of the cattle in the cattle corridor are being managed mainly under the extensive systems.

\subsubsection{Grassland (Grazing Land)}

Of the Uganda $241,547.7$ square kilometres area, the following classification has been made according to land use and cover.

\begin{tabular}{|c|c|c|c|}
\hline \multicolumn{4}{|c|}{ TABLE 3A } \\
\hline \multicolumn{4}{|c|}{ LAND-USE/COVER STRATIFICATION $\left(\mathrm{KM}^{2}\right)$} \\
\hline NO & TYPE & AREA (SQ. KM ${ }^{2}$ ) & $\begin{array}{c}\% \text { OF TOTAL } \\
\text { UGANDA AREA }\end{array}$ \\
\hline 1 & Open Water & $36,909.3$ & 15.3 \\
\hline 2 & Permanent Swamp & $7,709.5$ & 3.21 \\
\hline 3 & Forest Plantations & 345.2 & 0.14 \\
\hline 4 & Tropical High Forest (Reserves) & $15,250.4$ & 6.31 \\
\hline 5 & Woodland & $2,807.9$ & 1.15 \\
\hline 6 & Bushland & $14,198.7$ & 5.87 \\
\hline 7 & Grassland & $51,118.8$ & 21.15 \\
\hline 8 & Small scale Farm Land & $83,930.9$ & 34.74 \\
\hline 9 & Large scale Farm land & $11,115.0$ & 4.60 \\
\hline 10 & Mountains (Over 2000m) & $2,036.0$ & 0.85 \\
\hline 11 & Game Reserve and Parks & $15,620.0$ & 6.48 \\
\hline 12 & Other land (Urban Centres, etc.) & 506.0 & 0.20 \\
\hline & Total (Uganda) & $241,547.7$ & 100.00 \\
\hline
\end{tabular}

From the above, the following area can be classified as available for grazing (pasture) in Uganda. 
It is estimated that $56.9 \%$ of Uganda's total area $\left(241,547.7 \mathrm{Km}^{2}\right)$ is potential for feeding ruminant livestock. This comprises of a big fraction of the vegetation cover.

Otherwise in Uganda the following area is available as natural pasture:

\section{Category}

i) Wodland $(75 \%)$

ii) Bush (100\%)

iii) Grassland (100\%)

iv) Small Scale Farmland (50\%)

Total

\section{Area Km2}

30.208

14,198

51,118

41,965

137,469

\subsubsection{Gross Domestic Product (GDP)}

The means for achieving improved living conditions and greater material possessions usually comes through increasing the gross agricultural product (Thornton, D.D. 1968). Our livestock contributes significantly to the national production as evidenced by records of the GDP during the decade 1985 to 1995 :

\begin{tabular}{|c|c|c|c|}
\hline \multicolumn{4}{|c|}{ TABLE 3B } \\
\hline \multicolumn{4}{|c|}{ LIVESTOCK GDP IN AGRICULTURAL GDP, 1985 - 1995} \\
\hline \multirow[t]{2}{*}{ YEAR } & AGRICULTURAL GDP & \multicolumn{2}{|c|}{ LIVESTOCK GDP } \\
\hline & USHS. (MILLION) & $\begin{array}{c}\text { USHS. (MILION) } \\
000\end{array}$ & $\begin{array}{c}\% \text { OF } \\
\text { AGRICULTURAL } \\
\text { GDP } \\
\end{array}$ \\
\hline 1985 & 15.028 & 2,906 & 19.3 \\
\hline 1986 & 36.615 & 6,410 & 17.5 \\
\hline 1987 & 131,417 & 20,725 & 15.8 \\
\hline 1988 & 353,304 & 67,767 & 19.2 \\
\hline 1989 & 677.044 & 107,162 & 15.8 \\
\hline 1990 & 812,459 & 140,272 & 17.3 \\
\hline 1991 & $1,082,044$ & 191,693 & 17.7 \\
\hline 1992 & $1,896,189$ & 263,370 & 13.9 \\
\hline 1993 & $1,823,917$ & 296,022 & 16.2 \\
\hline 1994 & $2,493,305$ & 375,162 & 15.05 \\
\hline 1995 & $2,564,63$ & 440.599 & 17.2 \\
\hline Sources & \multicolumn{3}{|c|}{ 1. MFEP - Background to the Budget - 1992/93, June 1992.} \\
\hline & \multicolumn{3}{|c|}{ 2. MFEP - Statistical Abstract, 1990 - Entebbe, July 1996} \\
\hline
\end{tabular}




\subsection{Methodologies}

Effects of climate change and variability have been studied and investigated as outlined below:

\subsubsection{Methods used for Vulnerability and Adaptation Assessment}

Grasslands (rangelands) and livestock have been some of the sectors selected for the study of vulnerability in Uganda because of their economic significance to Uganda and high susceptibility to climate change and variability.

Vulnerability assessment has been developed by the use of climate scenarios derived from GCMs. Climate variables are used as model inputs and simulations first run under current conditions to provide a baseline scenario; then the climate parameters are adjusted to the area climate scenario, under several GCMs. The climate change impact can be attributed to the difference in the simulation outputs.

Vulnerability and adaptation assessment involved plant and animal components analysis including use of models.

\subsubsection{Plant species used in the assessment included:}

- warm (dry) season grass - Hyparrhenia rufa;

- cool (wet) seasons grass - Setaria sphacelata;

- warm (dry) season forbe - Tripsacum laxum;

- cool (wet) season forbe - Pennisetum purpcream; and

- shrub - Acacia hockii.

It was difficult to define exactly what a forbe was among our tropical plants. Hyparrhenia, setaria, pennisetum and acacia are a common feature in the rangelands under study. Data on plants here in Uganda was not adequate to run the SPUR2 Model.

\subsubsection{Animal Species (Breeds)}

A Zebu breed cattle (steer) was used in this assessment. This represents the commonly found cattle in the Eastern region of Uganda grazed along the corridor and up to the year 1978 it formed $70 \%$ of all the Ugandan national herd.

\subsubsection{The Model(s) used in the Assessment}

The Model used for simulation in this assessment was SPUR2 (Simulation of Production and Utilization of Rangelands) Model which also incorporates the CBCPM (Colorado Beef Cattle Production Model). 


\subsubsection{Modifications to the recommended Model}

\subsubsection{Plotting}

The plotting utility of the SPUR2 Model in DOS has not been possible especially after changing the data such as renaming and classification of the plant species. Lotus graphics were, therefore, used to which the climate "Pit" files were transferred.

\subsubsection{Forbes}

The fodder crops for Forbes were used because the exact equivalent in the tropical plants could not be got. I would have, however, preferred to use legumes, which are more often used to improve on the Nitrogen comment of our grass feeds rather than the fodder.

\subsubsection{Warm and Cool Seasons}

Here in Uganda the terms dry (hot) and wet (cool) seasons are used instead of the warm and cool season respectively. Using the carbon pathways, therefore, I have identified the dry (hot) and cool (wet) grass species and forbes as they can survive under either of the weather conditions.

\subsubsection{Sources of weather and Times Series Data}

Observed data for the years 1951 - 1980 was collected, as baseline data,. The Climate Variables included Temperature (Maximum and Minimum), precipitation, Solar radiation and wind speed. This data is mainly from a Research Station at Serere. The options for climate change scenarios used include mainly the General Circulation Models (GCMs) of UK89, GISS, CCCM and GFD $_{3}$.

Mean monthly data averages for over 30 years $(1951$ - 1980) for Serere Research Station were taken and differences for the different GCMs were also taken for simulation in the SPUR2 Model. Graphics figures $1-4$ were used and results interpreted as in Table 8.

\subsubsection{Selection of Study Site}

\subsubsection{RDI Assessment}

Considering the economic activities in different regions of Uganda, seven Districts namely: Moroto, Kotido, Soroti, Luwero, Masindi, Mubende and Mbarara (see location in figure 1.1) were evaluated and a sample Range Dependence Index (RDI) - taken from Soroti - was applied to determine the economic importance of livestock grazing in these Districts - income derived from grazing cattle by off-take per annum. 
Range Dependence Index (RDI) for the selected site was as follows:

Value of range livestock production = Ushs. 92,223/=

Total Farm Sales = Ushs. 103,259/=

Farm Income $\quad=\quad$ Ushs. $1,140,000 /=$

Total Income $\quad=\quad$ Ushs. $1,528,000 /=$

$\mathrm{RDI}=$ Value of Range Production X Farm Income $\times 100$

Total Farm Sales $X$ Total Income

$$
\begin{aligned}
& =\frac{9,223 \times 1,140 \times 100}{103,259 \times 1,528} \\
& =\frac{105,135,220 \times 100}{157,779,752} \\
& =66 \%
\end{aligned}
$$

Source: Baseline survey of Households in Uganda 1989

From the seven Districts whose economic activities centred greatly around livestock production, Serere Research Station in Soroti District had an ample quantity of data on most variables. Serere also enjoys a centroid location along the cattle corridor, and it was, therefore, selected as the chief simulation site. Data of the other sites especially on household incomes and expenditure were not adequate to warrant computation of RDI but here below is a summary of their quantity of livestock and the value of their products from the districts selected along the corridor as at 31st December 1995. 


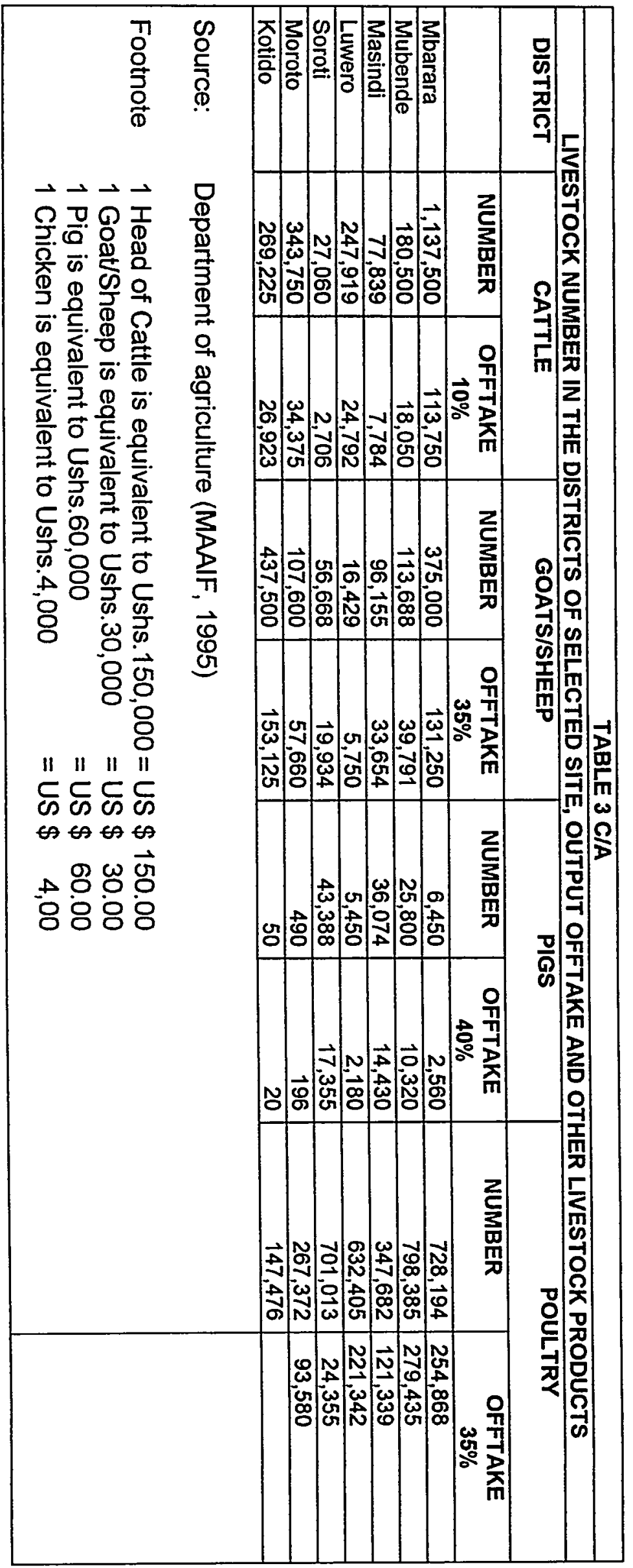




\begin{tabular}{|c|l|r|r|r|}
\hline \multicolumn{5}{|c|}{ TABLE 3 C/B } \\
\hline NO & DISTRICT & MILK (LITRES) & $\begin{array}{c}\text { VALUE* IN } \\
\text { (USHS.) }\end{array}$ & $\begin{array}{c}\text { VALUE IN } \\
\text { (US \$) }\end{array}$ \\
\hline 1 & Mbarara & $112,699,562$ & $28,174,890,500$ & $28,174,890.50$ \\
\hline 2 & Mubende & $27,797,359$ & $6,949,339,750$ & $6,949,339.75$ \\
\hline 3 & Masaka & $5,867,313$ & $1,466,828,250$ & $1,466,828.25$ \\
\hline 4 & Luwero & $22,679,965$ & $5,669,991,250$ & $5,669,991.25$ \\
\hline 5 & Soroti & $5,384,617$ & $1,346,154,250$ & $1,346,154.25$ \\
\hline 6 & Moroto & 26,458179 & $6,614,544,750$ & $6,614,544.75$ \\
\hline 7 & Kotido & $21,733,540$ & $5,433,385,000$ & $5,433,385.00$ \\
\hline \multirow{6}{|c|}{ Milk costing Ushs.250/= (US \$ 0.25) } \\
Source: \\
Production zone > targets: MAAIF (1995) \\
Hides and Skins \\
The seven districts had their total value of hides and skins of \\
Ushs.48,509,563.50 (US \$ 48,509.56) \\
\hline
\end{tabular}

\subsubsection{Setting up SPUR2 for the Climate Change Scenarios}

\subsubsection{Nominal Run}

This was conducted with historical data as collected at the study site (in this case only serere data was adequate). The simulation period had been chosen as 30 years (running from the years 1951 to 1980).

\subsubsection{2 $2 \times \mathrm{CO}_{2}$ Runs}

As for the above, the simulation period remained 30 years. The value for carbon dioxide $\left(\mathrm{CO}_{2}\right)$ concentration was, however, changed from 330 to $700 \mathrm{ppm}$.

\subsubsection{GCM Runs}

Similar to the above setting, period of GCM simulation was 30 years and at elevated carbon dioxide $\left(\mathrm{CO}_{2}\right)$ concentration from 330 to $700 \mathrm{ppm}$.

The Serere grid was entered as latitude $1^{0} 31^{\prime}$, longitude $33^{\circ} 7^{\prime}$ and the GCM adjustment statistic for each month (monthly averages difference and ratios for the climate parameters entered except wind values). In DOS, however, and may be because inadequate data which was also of tropical nature SPUR2 did not run to plot. These climate "plt" files were consequently transferred onto the Lotus graphics to produce 
what is now seen in figures 3.1 to 3.4 for the 4 GCM modes (UK 89, GFD3, GISS and CCCM).

3.2.8.4 Livestock and Acreage

The Analysis at Serere site was taken to involve 30 head of cattle on 150 acres of land (60.73 ha).

\subsection{Results (Diagnosis of the Problems of Climate Change and Variability)}

\subsubsection{Study Site Results by Climate Change Scenarios}

As summarized in the discussion and conclusion below (see 5), simulation, predicted changes in biotic processes as follows:

\subsubsection{Temperature and Precipitation}

The UK89 and GFD3 GCMs predicted a higher annual mean temperature and precipitation for the Serere site. Whereas CCM and GISS GCMs predicted a decrease.

\subsubsection{Peak Standing Crop (PSC)}

Following temperature and precipitation changes there is some predicted increase in the peak standing crop (above ground biomass) temporarily.

\subsubsection{Soil Organic Matter (SOM)}

Briefly, the organic matter, as a nutrient, was utilized in the growth of the plants.

\subsubsection{Carbon: Nitrogen Ratio (C:N)}

As the soil organic matter is disorganized, the Nitrogen is picked up by the plant and hence reduced under the ground. The exact measurements of the changes in the above parameters remain difficult because of the lack of the equipment. 


\begin{tabular}{|c|c|c|c|c|c|c|c|c|c|}
\hline \multicolumn{10}{|c|}{ TABLE 3 D } \\
\hline \multicolumn{10}{|c|}{ UK89 - SERERE DATA SIMULATION } \\
\hline MONTH & \multicolumn{3}{|c|}{ TEMPERATURE (C) } & \multicolumn{3}{|c|}{ PRECIPITATION (MM/DAY } & \multicolumn{3}{|c|}{ SOLAR (W/M2) } \\
\hline & $1 \times \mathrm{CO}_{2}$ & $2 \mathrm{XCO}_{2}$ & DIFF & $1 \mathrm{XCO}_{2}$ & $2 \mathrm{XCO}_{2}$ & RATIO & $1 \mathrm{XCO}_{2}$ & $2 \mathrm{XCO}_{2}$ & RATIO \\
\hline 1 & 22.5 & 24.9 & 2.46 & 1.8 & 0.7 & 0.37 & 230 & 243 & 1.05 \\
\hline 2 & 22.6 & 27.2 & 4.58 & 2.1 & 1.3 & 0.63 & 238 & 249 & 1.05 \\
\hline 3 & 23.5 & 28.8 & 5.26 & 3.8 & 1.9 & 0.5 & 231 & 248 & 1.08 \\
\hline 4 & 22.0 & 26.2 & 4.23 & 6.0 & 6.4 & 1.07 & 211 & 222 & 1.05 \\
\hline 5 & 21.0 & 24.8 & 3.79 & 4.3 & 5.7 & 1.32 & 209 & 217 & 1.04 \\
\hline 6 & 20.7 & 24.0 & 3.28 & 1.9 & 2.9 & 1.49 & 239 & 235 & 0.98 \\
\hline 7 & 20.0 & 23.8 & 3.88 & 2.7 & 2.2 & 0.83 & 205 & 216 & 1.06 \\
\hline 8 & 20.2 & 24.2 & 3.99 & 2.8 & 2.7 & 0.98 & 206 & 208 & 1.01 \\
\hline 9 & 21.5 & 24.9 & 3.42 & 2.9 & 4.0 & 1.37 & 246 & 225 & 0.92 \\
\hline 10 & 22.4 & 25.6 & 3.17 & 2.1 & 2.8 & 1.32 & 261 & 255 & 0.98 \\
\hline 11 & 22.7 & 25.6 & 2.85 & 2.4 & 3.1 & 1.31 & 232 & 232 & 1.00 \\
\hline 12 & 21.8 & 24. & 2.93 & 2.1 & 2.6 & 1.22 & 227 & 210 & 0.93 \\
\hline
\end{tabular}

\begin{tabular}{|c|c|c|c|c|c|c|c|c|c|}
\hline \multicolumn{10}{|c|}{ TABLE $3 \mathrm{E}$} \\
\hline \multicolumn{10}{|c|}{ GFD3 - SERERE DATA SIMULATION } \\
\hline MONTH & \multicolumn{3}{|c|}{ TEMPERATURE (C) } & \multicolumn{3}{|c|}{ PRECIPITATION (MM/DAY } & \multicolumn{3}{|c|}{ SOLAR (W/M2") } \\
\hline No & $1 \mathrm{XCO}_{2}$ & $2 \mathrm{XCO}_{2}$ & DIFF & $1 \mathrm{XCO}_{2}$ & $2 \mathrm{XCO}_{2}$ & RATIO & $1 \mathrm{XCO}_{2}$ & $2 \mathrm{XCO}_{2}$ & RATIO \\
\hline 1 & 19.9 & 22.4 & 2.51 & 4,0 & 4.4 & 1.09 & 237 & 238 & 1.05 \\
\hline 2 & 20.8 & 23.3 & 2.55 & 4.4 & 4.9 & 1.1 & 252 & 258 & 1.02 \\
\hline 3 & 20.9 & 22.9 & 2.08 & 5.6 & 8.1 & 1.45 & 242 & 240 & 0.99 \\
\hline 4 & 19.9 & 22.0 & 2.08 & 8.0 & 9.0 & 1.05 & 213 & 220 & 1.03 \\
\hline 5 & 18.4 & 20.7 & 2.31 & 6.6 & 7.7 & 1.17 & 190 & 193 & 0.99 \\
\hline 6 & 17.4 & 20.2 & 2.85 & 5.1 & 5.7 & 1.11 & 182 & 198 & 1.09 \\
\hline 7 & 17.3 & 20.8 & 3.56 & 5.0 & 6.0 & 1.23 & 185 & 201 & 1.16 \\
\hline 8 & 18.3 & 21.5 & 3.18 & 6.1 & 7.0 & 1.15 & 186 & 198 & 1.07 \\
\hline 9 & 19.4 & 21.9 & 2.53 & 6.8 & 7.9 & 1.17 & 214 & 212 & 0.99 \\
\hline 10 & 20.1 & 22.6 & 2.55 & 5.1 & 6.2 & 1.21 & 248 & 256 & 1.03 \\
\hline 11 & 19.4 & 22.2 & 2.82 & 6.7 & 8.1 & 1.21 & 221 & 227 & 1.03 \\
\hline 12 & 19.4 & 21.8 & 2.59 & 4.0 & 4.9 & 1.22 & 244 & 229 & 0.94 \\
\hline
\end{tabular}

\begin{tabular}{|c|c|c|c|c|c|c|c|c|c|}
\hline \multicolumn{10}{|c|}{ TABLE $3 \mathrm{~F}$} \\
\hline \multicolumn{10}{|c|}{ CCCM - SERERE DATA SIMULATION } \\
\hline MONTH & \multicolumn{3}{|c|}{ TEMPERATURE (C) } & \multicolumn{3}{|c|}{ PRECIPITATION (MM/DAY } & \multicolumn{3}{|c|}{ SOLAR (W/M2") } \\
\hline No & $1 \mathrm{XCO}_{2}$ & $2 \mathrm{XCO}_{2}$ & DIFF & $1 \times \mathrm{CO}_{2}$ & $2 \mathrm{XCO}_{2}$ & RATIO & $1 \times \mathrm{CO}_{2}$ & $2 \mathrm{XCO}_{2}$ & RATIO \\
\hline 1 & 17.4 & 20.0 & 2.64 & 3.9 & 4.4 & 1.13 & 210 & 201 & 0.96 \\
\hline 2 & 18.1 & 20.6 & 2.44 & 4.4 & 6.0 & 1.37 & 220 & 208 & 0.94 \\
\hline 3 & 19.1 & 21.1 & 1.94 & 6.6 & 6.2 & 0.94 & 224 & 223 & 0.99 \\
\hline 4 & 19.1 & 21.4 & 2.35 & 5.1 & 7.1 & 1.38 & 236 & 208 & 0.88 \\
\hline 5 & 18.9 & 21.2 & 2.24 & 7.0 & 6.2 & 0.88 & 212 & 200 & 0.95 \\
\hline 6 & 18.4 & 20.6 & 2.2 & 4.7 & 3.2 & 0.68 & 209 & 217 & 1.04 \\
\hline 7 & 18.1 & 20.1 & 1.96 & 3.4 & 2.2 & 0.64 & 228 & 232 & 1.02 \\
\hline 8 & 18.4 & 20.5 & 2.12 & 3.9 & 3.8 & 0.97 & 225 & 220 & 0.98 \\
\hline 9 & 18.8 & 21.2 & 2.38 & 6.9 & 6.5 & 0.95 & 205 & 200 & 0.97 \\
\hline 10 & 18.3 & 20.8 & 2.46 & 7.0 & 7.4 & 1.05 & 204 & 185 & 0.91 \\
\hline 11 & 18.0 & 20.0 & 2.06 & 4.2 & 4.9 & 1.17 & 205 & 189 & 0.92 \\
\hline 12 & 17.5 & 20.2 & 2.64 & 4.3 & 4.1 & 0.96 & 200 & 194 & 0.97 \\
\hline
\end{tabular}




\begin{tabular}{|c|c|c|c|c|c|c|c|c|c|}
\hline \multicolumn{10}{|c|}{ TABLE 3 G } \\
\hline \multicolumn{10}{|c|}{$\begin{array}{c}\text { GISS - SERERE DATA SIMULATION } \\
\end{array}$} \\
\hline MONTH & \multicolumn{3}{|c|}{ TEMPERATURE (C) } & \multicolumn{3}{|c|}{ PRECIPITATION (MM/DAY } & \multicolumn{3}{|c|}{ SOLAR (W/M2") } \\
\hline No & $1 \mathrm{XCO}_{2}$ & $2 \mathrm{XCO}_{2}$ & DIFF & $1 \mathrm{XCO}_{2}$ & $2 \mathrm{XCO}_{2}$ & RATIO & $1 \mathrm{XCO}_{2}$ & $2 \times \mathrm{CO}_{2}$ & RATIO \\
\hline 1 & 21.5 & 25.7 & 4.24 & 5.3 & 5.8 & 1.08 & 248 & 255 & 1.03 \\
\hline 2 & 22.2 & 26.2 & 3.99 & 5.4 & 6.3 & 1.16 & 261 & 266 & 1.02 \\
\hline 3 & 22.5 & 26.7 & 4.18 & 6.2 & 6.8 & 1.14 & 268 & 274 & 1.02 \\
\hline 4 & 22.6 & 26.8 & 4.21 & 5.7 & 6.8 & 1.19 & 262 & 269 & 1.02 \\
\hline 5 & 22.9 & 26.3 & 3.42 & 4.8 & 6.4 & 1.33 & 249 & 254 & 1.02 \\
\hline 6 & 23.1 & 26.1 & 3.04 & 4.8 & 6.2 & 1.3 & 245 & 246 & 1.01 \\
\hline 7 & 23.3 & 26.1 & 2.81 & 4.3 & 6.3 & 1.47 & 248 & 246 & 0.99 \\
\hline 8 & 23.1 & 26.1 & 2.99 & 5.7 & 5.8 & $1 . .0$ & 259 & 255 & 0.99 \\
\hline 9 & 22.7 & 26.2 & 3.5 & 6.2 & 6.4 & 1.04 & 261 & 270 & 1.03 \\
\hline 10 & 22.4 & 26.2 & 3.88 & 5.9 & 6.7 & 1.13 & 257 & 264 & 1.03 \\
\hline 11 & 21.6 & 25.3 & 3.7 & 5.3 & 5.8 & 1.08 & 247 & 253 & 1.02 \\
\hline 12 & 21.4 & 25.4 & 3.98 & 5.3 & 5.4 & 1.02 & 246 & 253 & 1.03 \\
\hline
\end{tabular}




\section{UK 89 MODEL}

(Output for Serere Agromet. Stn)

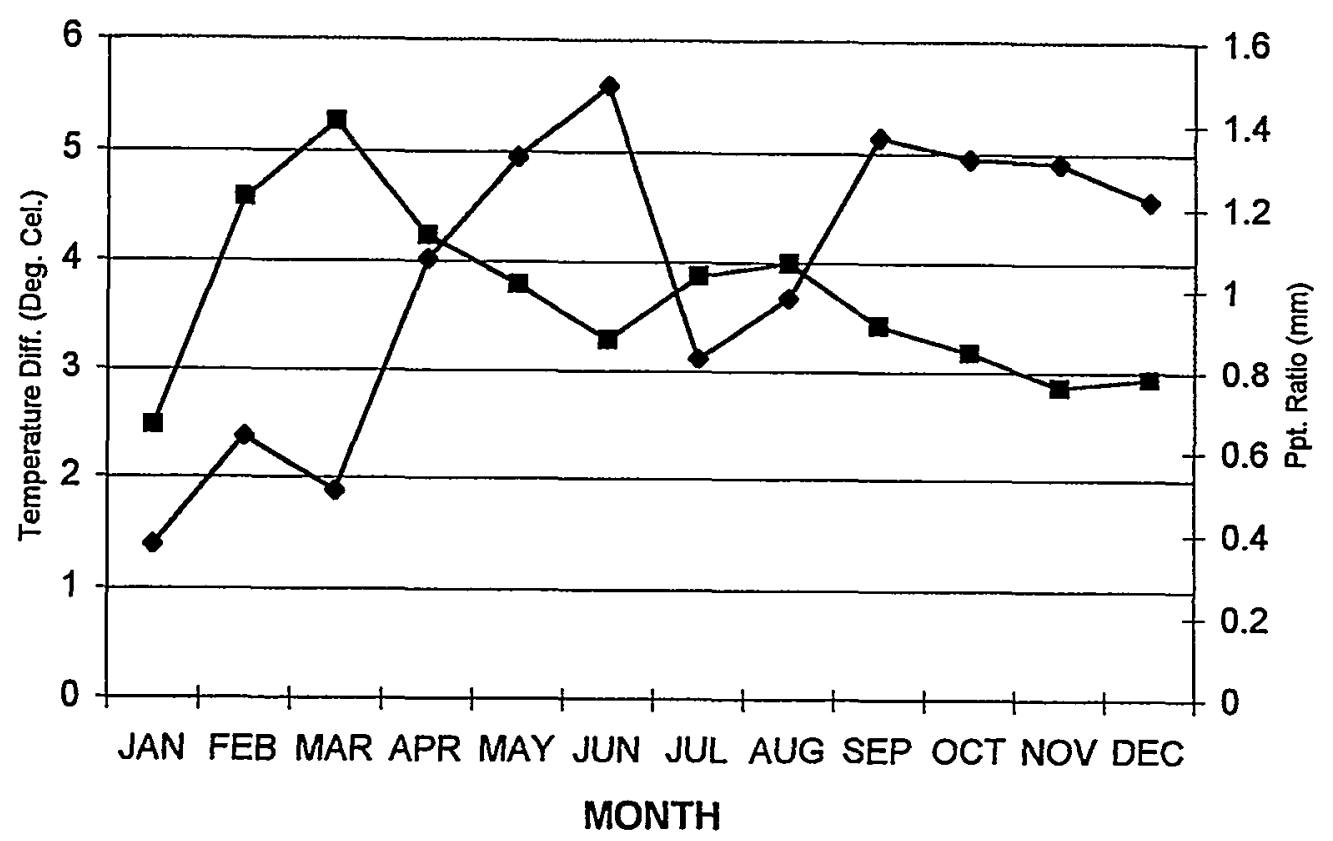

$\rightarrow-$ Temp (Deg. Cel.) $\leadsto$ Ppt. (mm)

FIGURE 3.1 


\section{GFD3 MODEL \\ (Output for Serere Agromet. Stn.)}

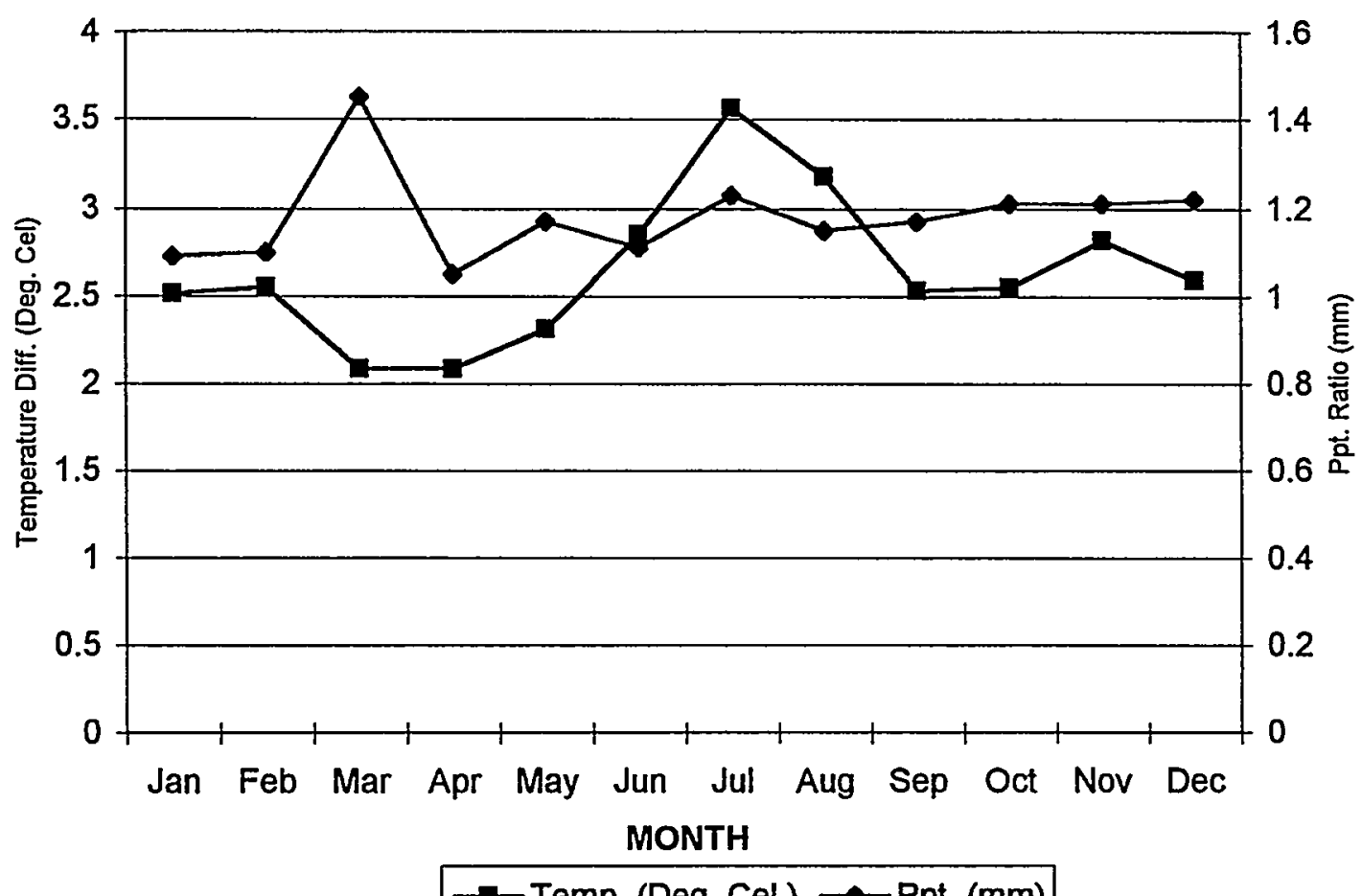

$\rightarrow$ Temp. (Deg. Cel.) $\leadsto$ Ppt. (mm)

FIGURE 3.2 
CCCM MODEL

(Output for Serere Agromet. Stn)

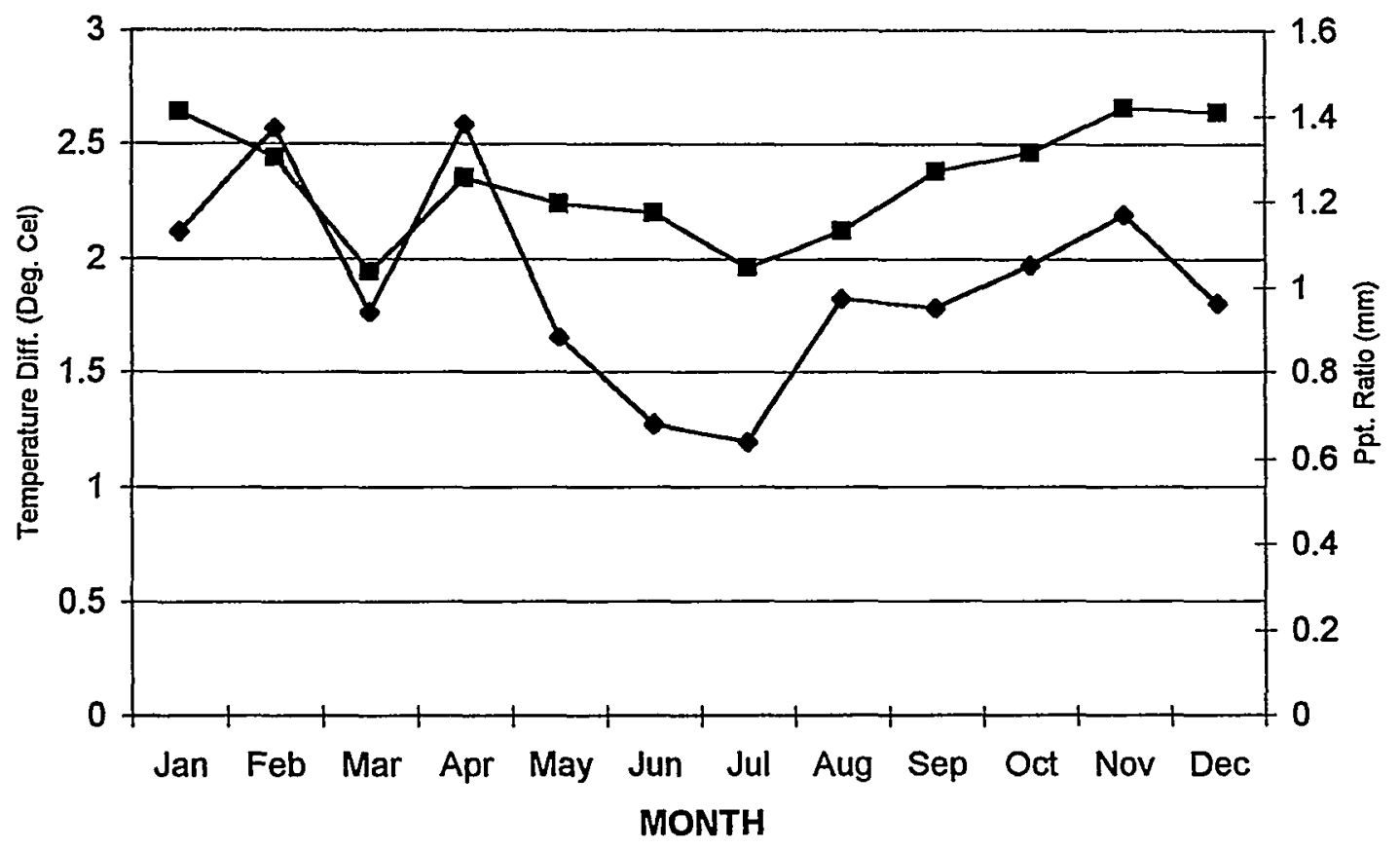

$\rightarrow$-Temp (Deg.cel.) $\longrightarrow$ Ppt. (mm)

FIGURE 3.3 
GISS MODEL

(Output for Serere Agromet. Stn.)

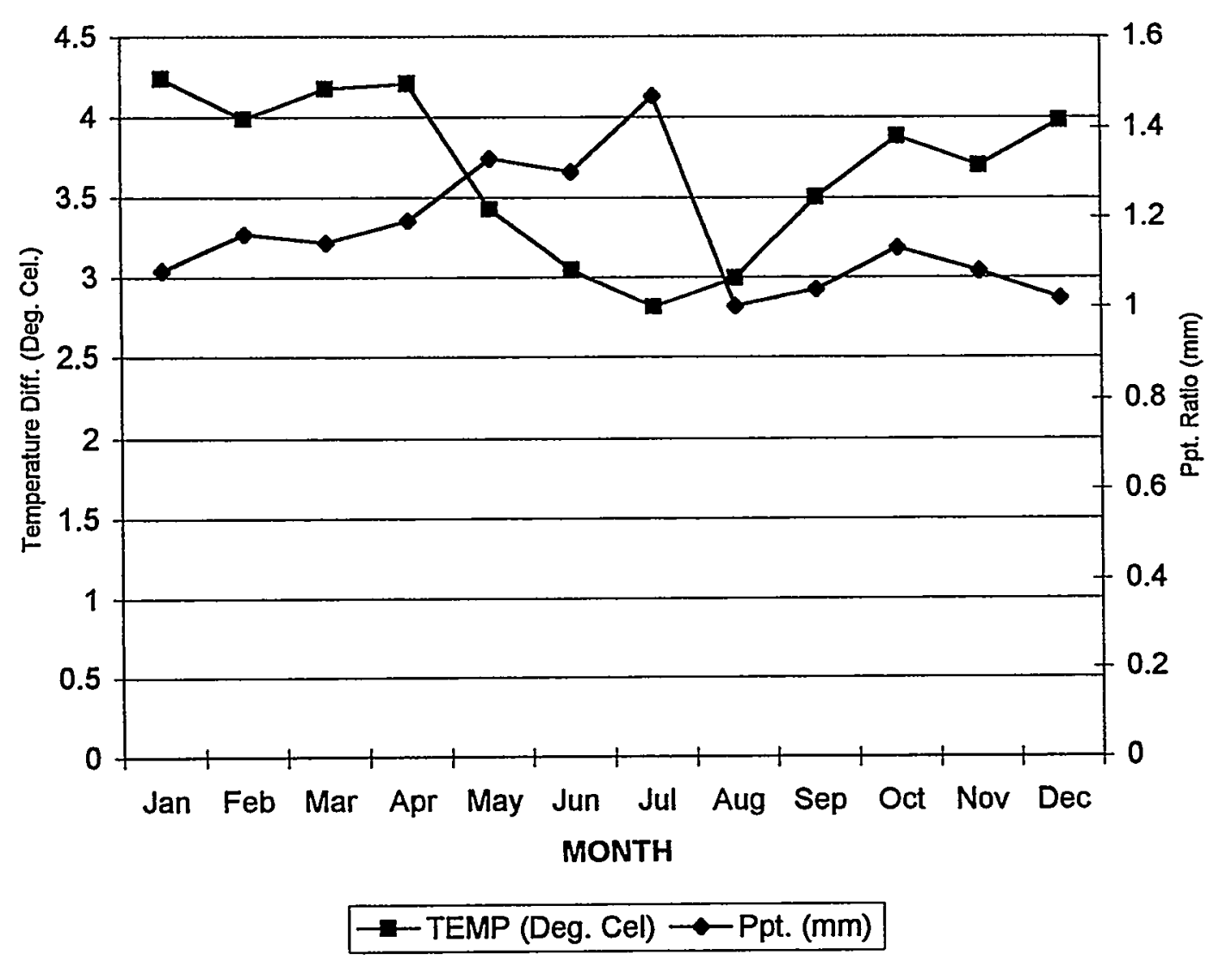

FIGURE 3.4

29 


\begin{tabular}{|c|c|c|c|c|c|c|c|}
\hline & & & & 3LE $3 \mathrm{H}$ & & & \\
\hline SPUR2 GF & ASSLAND & $\begin{array}{l}\text { STOCK RE } \\
\text { THE TEM }\end{array}$ & $\begin{array}{l}\text { ULTS BY } \\
\text { ERATURE }\end{array}$ & $\begin{array}{l}\text { IMATE CHANG } \\
\text { FFERENCES A }\end{array}$ & $\begin{array}{l}\text { SCENARIOS } \\
\text { D PRECIPITA }\end{array}$ & $\begin{array}{l}\text { SMs) RUN } \\
\text { ONS }\end{array}$ & $2 \times \mathrm{CO}_{2}$ \\
\hline & & $\begin{array}{c}\text { Peak } \\
\text { Standing } \\
\text { Cropg } / \mathrm{m}^{2} \\
\text { /year }\end{array}$ & $\begin{array}{c}\text { Soil } \\
\text { Organic } \\
\text { matter } \\
(\%)\end{array}$ & $\begin{array}{c}\text { Carbon/Nitro } \\
\text { gen Ratio at } \\
\text { depth 0-18 } \\
\mathrm{cm}\end{array}$ & $\begin{array}{c}\text { Milk } \\
\text { Production } \\
\text { Kg/head }\end{array}$ & $\begin{array}{c}\text { Grazed } \\
\text { Forage } \\
\mathrm{Kg} / \mathrm{head} / \mathrm{an} \\
\text { num }\end{array}$ & $\begin{array}{c}\text { Weights } \\
\text { Market } \\
\text { Kg/head }\end{array}$ \\
\hline $\begin{array}{l}\text { Without } \\
\text { Adaptation }\end{array}$ & $\begin{array}{l}\text { Baseline } \\
\text { Condition }\end{array}$ & 3400 & $2.1-3.3$ & $2.3: 0.18(12.8)$ & 1340 & 10.900 & 380 \\
\hline & $\begin{array}{l}\text { UK89 } \\
\text { Change } \\
\text { Scenario }\end{array}$ & Increase & Decrease & Decline & Increases & Increase & Increase \\
\hline & $\begin{array}{l}\text { GFD3 } \\
\text { Change } \\
\text { Scenario }\end{array}$ & Increased & Decrease & Decline & Increases & Increase & Increases \\
\hline & $\begin{array}{l}\mathrm{CCM} \\
\text { Change } \\
\text { Scenario }\end{array}$ & Decrease & Increase & Rises & Decrease & Decrease & Decrease \\
\hline & $\begin{array}{l}\text { GISS } \\
\text { Change } \\
\text { Scenario }\end{array}$ & Decrease & Increase & Rises & Decrease & Decreases & Decrease \\
\hline
\end{tabular}

\subsection{Possible Adaptation Measures}

In Uganda now it is recognised that it is not lack of technical knowledge which is a limiting factor in provision of say Animal Protein but the major hand carp is the lack of understanding about and use of basic investment criteria, resource use principles and analysis at the production system level. Most of the animal protein (meat and milk) consumed in this country is being produced under the traditional systems of animal husbandry including communal grazing and nomadism. This type of husbandry is very vulnerable to any climate change or variability.

Our current policies among other things encourage promotion of use of appropriate breeds through natural and artificial breeding so as to increase productivity in the different agro-ecological zones.

The government has an objective of improving forage and feed production and supply of water to livestock.

All production must be guided under a friendly and sustainable environment. Increasing pressure on land is obvious and hence the necessity for wise and foresighted land use planning.

In response to the possible climate change and its impact on the production of the rangeland grasslands and livestock as simulated by SPUR2 model and for sustainable livestock production along the Uganda cattle corridor, the following alternative adaptations may have to be considered: 


\subsubsection{Medium Term Responses}

Medium Term adaptation options can be categorised as follows:
3.4.1.1
By Time

- Perfect Early Warning to farmers:

- Improve on research and intensify extension on sustainable agriculture and farming methods:

- Reduce on post harvest losses: and

- Improve on storage facilities.

\subsubsection{By level of Action}

- Individual

- Farmers to start improving productivity of their plots:

- Increase yield;

- Ensure food security by storing adequate non-perishable foods;

- Diversifying production enterprises for income generating.

\subsubsection{At Household level}

- Animal traction may be revitalised; and

- Use of organic fertilisers.

\subsubsection{Long-Term Strategies (Adaptation Options)}

\subsubsection{Existing Laws}

For long term planning it may be necessary to review some old Uganda Laws and policies concerned with the environment and farming practices.

The following can be cited as examples:

- The Cattle Grazing Act (1964)

This was meant to provide for control and regulation of grazing of cattle so as to prevent overstocking and the resultant overgrazing and soil degradation.

- The Animal Disease Act (1964)

This among other things provides for the control and prevention of spread of animal diseases by regulating animal movements. 
This provides for the control of straying of animals. Soon with pressure on land, nomadism may have no room for free mobility and it may become straying.

- The Water Works Act (1964)

This provided for supply of clean water to the public.

- The tsetse Control Act (1964)

For the control and prevention of spread of tsetse fly - which hampers livestock and human production.

- Prohibiting of burning of Grass Degree (174)

To support the Government Policy on burning of grass.

While these and many other Uganda and International Laws are being reviewed to make them more applicable and effective than they are now, we must focus our attention at the impending serious climate change and variability so as to formulate some mitigation adaptation options similar to what have attempted to outline here below:-

\subsubsection{Grazing Management}

The current traditional way of animal husbandry must be remodelled into modern systems such as :-

\subsubsection{Sedentary Farming}

Where the nomadic stock owners will have to break their culture through training and persuasion to settle in one place which they can fence and if possible practice mixed farming - crop and animal farming; thereby avoid straying. Here the Government will be able to provide essential services to these communities such as water, veterinary, health, schools and marketing. The cattle owners will also be able to spread risks beyond cattle to other enterprises. By settling on one piece of land cattle numbers will have to be trimmed to meet the carrying capacity of the rangelands.

\subsubsection{Rotational Grazing}

With settled farming this type of husbandry can be practised and manure (organic matter) can be added to the soil evenly and in sufficient amounts to balance the "SOM". Rotation grazing has the advantage of planned mixed farming, controlling defoliation, 
worm control and resting of different portions of land at various intervals, possible example is outlined below.

\begin{tabular}{|l|l|l|}
\hline \multicolumn{3}{|c|}{ TABLE 3 I } \\
\hline \multicolumn{2}{|c|}{ DEFERRED GRAZING SYSTEM (OVER 2 YEARS) } \\
\hline $\begin{array}{l}\text { First 6 months } \\
\text { (October - April) }\end{array}$ & Area 1 & \multicolumn{1}{c|}{ Area 2 } \\
\hline $\begin{array}{l}\text { Second 6 months } \\
\text { (April - October) }\end{array}$ & $\begin{array}{l}\text { Herd A } \\
\text { Herd B }\end{array}$ & Herd B \\
\hline $\begin{array}{l}\text { Third 6 months } \\
\text { (October - April) }\end{array}$ & Herd A & Empty Burn in October \\
\hline $\begin{array}{l}\text { Fourth 6 months (April- } \\
\text { October) }\end{array}$ & Empty Burn in August & $\begin{array}{l}\text { Herd A } \\
\text { Herd B }\end{array}$ \\
\hline
\end{tabular}

\subsubsection{Feed Lot}

This type of cattle management completely eliminates the extremes of weather variability and encourages feed conservation and utilization including hay and silage making and use of crop residues such as sugar bagasse and stobber or straw. It is an expensive enterprise but if undertaken near the markets as a finishing spot can be very profitable.

\subsubsection{Carrying Capacity (Stocking Rates)}

Our rangelands have been analyzed to produce the following quantities of dry matter at different points along the cattle corridor. When cattle roam all over the place as is the case now, it is difficult to control the sustainability of the environment. As an adaptation alternative, the carrying capacities of various vegetation covers may have to be indicated when advising (see Table $3 \mathrm{~J}$ ). Maintain sufficient grazing pressure so that cattle eat everything uniformly - not just the most palatable and leaving the unpalatable.

\begin{tabular}{|l|c|c|c|}
\hline \multicolumn{4}{|c|}{ TABLE 3 J } \\
\hline REGION & $\begin{array}{c}\text { SAFE RELEASABLE } \\
\text { PRODUCTION DMP } \\
\text { (kg/ha/annum) }\end{array}$ & $\begin{array}{c}\text { GROWTH REQUIREMENT } \\
\text { LSU (KG/ANNUM) }\end{array}$ & ICC(ha/LSU) \\
\hline North & 1,778 & 3,513 & 1.98 \\
\hline Central & 3,671 & 3,513 & 0.96 \\
\hline South & 1,353 & 3,513 & 2.60 \\
\hline \multicolumn{4}{|c|}{ Source: Review of the second Beef Ranching Development Project (1984) } \\
\hline
\end{tabular}




\section{Calving Periods}

Currently, our stockowners have not taken calving period as a management tool one can control to his advantage especially as regards food supply. We may have to advise adaptation routinisation of calving such that it occurs at a time when cows will have plenty to eat for maintenance and production.

\subsubsection{Water Management}

Along this cattle corridor water is available in various forms, lakes, rivers, valley tanks and dams. Accessibility to these water sources is not uniform and therefore during climate change or variability there is disorder especially as animals and people must move long distances in search of water. This sometimes means also aggregating at one water point and destroying the surrounding. As we anticipate hardship with climate change, water use should be planned and managed in such a way that adequate clean water is accessible without destruction to the environment and settlement. Disease spreading will also be reduced.

Lack of ownership especially of land discourages responsibility over the communal properties.

It is, therefore, recommended as a policy to harvest and provide adequate water for each population at strategic point along the cattle corridor so that sedentary farming can be achieved for sustainable agriculture and environment. In some communities cultural barriers have to be overcome through sensitisation. The energy saved by the animal from moving long distances will go into increased body weight gains and milk production and hence more income for the owner to improve his/her state. It will be necessary to establish fodder banks for the period of scarcity - dry season.

By mobilisation and training, water committees must be established to manage each watering point. The water source must also be improved enough to serve the human population around.

Where large dams or valley tanks are established, use of them can be made for fish farming and small-scale irrigation.

\subsubsection{Agroforestry and Integrated Farming}

A deliberate policy is needed to encourage Agroforestry such that suitable trees are planted on cattle ranches or farms. Trees are multi-purpose in the sense that they will provide shade for the animals from the tropical sum, break wind speed and thus stop wind erosion and any other damage of farm structures, fix nitrogen if leguminous, provide fuel, fencing poles and can act as fodder banks. Suitable trees will be recommended according to the circumstances of the area on the rangelands. 
The farming system on the rangelands should be of integrated agriculture to avoid calamity losses and spread risks. Also for food chain, it is necessary to encourage mixed enterprises. Livestock and crops are complementary to a large extent and production per unit land can be increased and vegetation cover helps to filter soil from the run-off.

Figure 3.5: Possible Systems of Integration

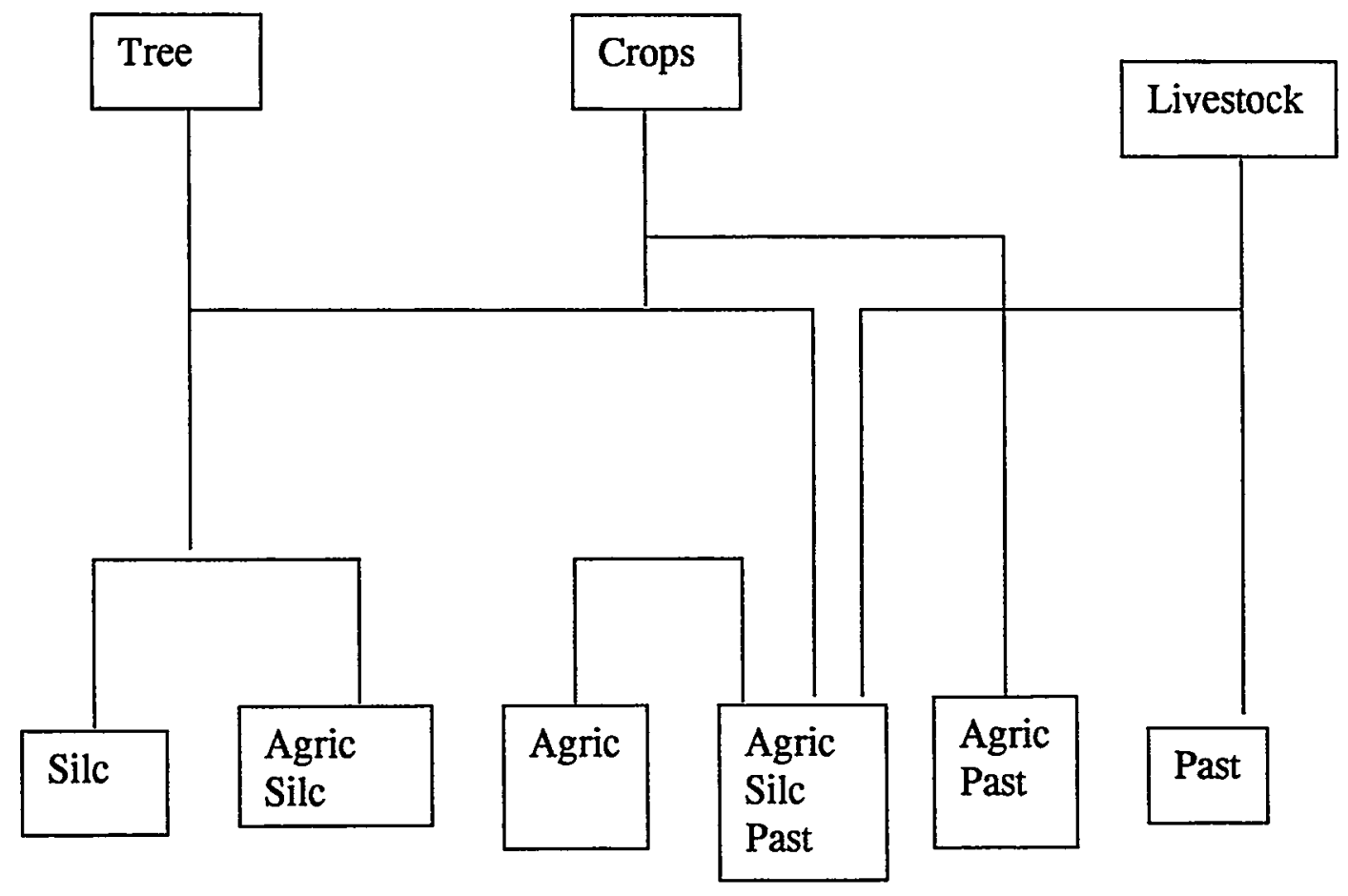

\subsubsection{Animal Breeding}

\subsubsection{Factors to be considered}

Many factors do guide policy formulation on animal breeding especially in developing countries like Uganda:

- Increasing Human Population

Increasing human population does not only demand more consumable protein but creates pressure on land such that arable land increases while grazing land decreases. A balance must therefore be found. Ugandan human population is increasing at a rate of about $2.8 \%$ while cattle population increases by about $1.5 \%$. 
- Market

Milk market locally has been much better for Uganda than meat. As purchasing power of the people improves much more meat must be made available even under the climate change and variability.

- Disease Situation

Disease situation has threatened up-grading of cattle or even importation of pure exotic cattle.

- Availability of Germplasm

For a long time we have relied on importation of exotic Germplasm for improvement of our indigenous breeds.

-. Climate

There is usually a comfortable zone for ceiling production of the different species and breads of animals, comfortable temperature and relative humidity.

\subsubsection{Breeding Adaptation (the Genotype)}

From the above analysis of some of the factors guiding the policy, one would suggest the following programmes to adapt to the likely climate change and variability:

\section{-. Selection}

The present composition of our national herd is about $96 \%$ indigenous breeds of cattle (East Africa Zebu and the sanga-long horn). These animals are handy as far as our climate is concerned and may be would manage through the potential climate change. Their production (meat and milk) is very low about 1,500 litres of milk per year(lactation) and yet in the temperate countries some breeds are producing up to 9,000 litres of milk. The same animal slaughter may yield only about 125 kilograms (dressed carcass). These levels are achieved after 5-6 years of the animal's life. A policy to reduce on maturing age and increasing production and productivity must be found. By selection among the indigenous breeds themselves one can isolate cattle whose production is adequately high and can multiply them.

\section{-. Cross-breeding}

The other method would be to upgrade the indigenous by crossing (bull or artificial insemination) with the temperate breeds. This will halve the maturity age triple production. If this method has to be employed, however, crossing to hybrid levels of $50 \%$ could be recommended so that the grade animal is better quality and retains the 
immunity to the environment. An animal which would mature in three years and give a dressed carcass of at least $250 \mathrm{kgs}$ would be preferred.

\subsubsection{Early Warning}

Modern technology for predictions of climate change and variability in addition to the indigenous knowledge should be perfected to a high degree of sensitivity.

\subsubsection{Food Reserves}

The previous severe floods and droughts have taught us a lesson at individual and national levels. Post harvest losses and food/feed conservation must therefore be a Government priority.

\subsubsection{Game ranching:}

For more complete grazing matric game ranching may have to be encouraged to utilise the plant communities beneficially. It should, however, be noted that, the bulk of game animals inhabit the grass plain and savannah or wooded grassland of Uganda where rainfall is often low and erratic. The options therefore is that game ranching is developed or wild animals give way to domestic livestock being the major competitor with game for the range resources. (Thorton (1968).

\subsubsection{Further Research}

Sampling and analysis of the vegetation cover by stratification should be a continuos exercise to determine the carrying capacity of the rangelands (maximum or optimal stocking rates) as the changing of climate will effect the land and its status. Actual Economics associated with climate change effects on livestock production need further investigation.

\subsection{Discussion and Conclusion}

\subsubsection{Temperature and Precipitation}

The mean annual temperatures were increased as predicted by the UK89, GDF3 and CCM models. Participation was increased for the GDF3 model.

\subsubsection{Peak Standing Crop (PSC)}

With increased precipitation there will be an expected increase in peak standing crop biomass above the ground. Thus being run for doubled Carbon Dioxide $\left(2 \times \mathrm{CO}_{2}\right)$ it has been shown that a growth increase of $0-10 \%$ may occur in the tropical pasture grasses which are mainly of C4 pathway (Warrick et all, 1986). 


\subsubsection{Soil Organic Matter (SOM)}

As a nutrient to the plant this organic matter is quickly decomposed and the nitrogen is utilised in this above the ground growth (PSC). In our ranglands where cattle keepers tend to be nomadic, replenishment of SOM is not adequate. Higher temperatures will encourage more rapid maturation of plants but for shorter period.

\subsubsection{Carbon: Nitrogen (C:N) Ratio}

As stated above, higher temperatures will encourage more rapid maturation of plants but for a shorter period. Therefore the increased production may not be very important especially when the below ground Nitrogen gets assimilated into the plant and eventually animal production is not replenished. This soon reduces the forage quality and animal production.

Increased ambient temperatures reduce forage quality and thereby decreasing animal production and this calls for a good management system.

\subsubsection{Nutritive Value of Uganda Grasses}

Even on an annual basis Uganda grasses have demonstrated variations in their nutritive values as affected by seasons and therefore in view of potential climate change there is need of intensifying management studies: with an objective of greater overall utilisation of pastures. The picture is same all over the cattle corridor, analysis having done in the four districts of Luwero, Kotido, Moroto and Mbarara. Table 11 below. In a cutting and burning experiment, crude protein analysis from plots cut at 4 weekly intervals, crude protein values varied between 10.30 and 4.07 percent. Even with 8-weekly cutting values ranged between 8.65 and 3.75 percent crude protein (Thornton DD 1966).

\begin{tabular}{|c|c|c|c|c|c|c|c|c|c|c|c|c|c|}
\hline \multirow{3}{*}{ Date } & \multicolumn{13}{|c|}{ PERCENTAGE CRUDE PROTEIN FROM FIRE-PROTECTED PLOTS CUT ON A FOUR-WEEKLY BASIS (1959-1960) } \\
\hline & 1959 & & & & & & 1959 & & & & & & \\
\hline & $4 / 9$ & $2 / 14$ & $30 / 14$ & $22 / 11$ & $25 / 12$ & $22 / 1$ & $19 / 2$ & $15 / 4$ & $19 / 5$ & $10 / 6$ & $8 / 7$ & $8 / 7$ & $5 / 8$ \\
\hline cp \% & 9.47 & 8.22 & 6.59 & 8.31 & $10 . .30$ & 9,80 & 7.86 & 10.11 & $8 / 40$ & 5.85 & 4.66 & 4.66 & 4.07 \\
\hline
\end{tabular}

From the above experiments, we can see that whereas starch equivalents values are always adequate for both maintenance and an element of a production throughout the year, protein is frequently limited (Masharll et al, 19961; Bredon and Torrel, 19962; Bredon and Marshall, 1962); Bredon and Wilson, 1963). Also see figure 3.6. 


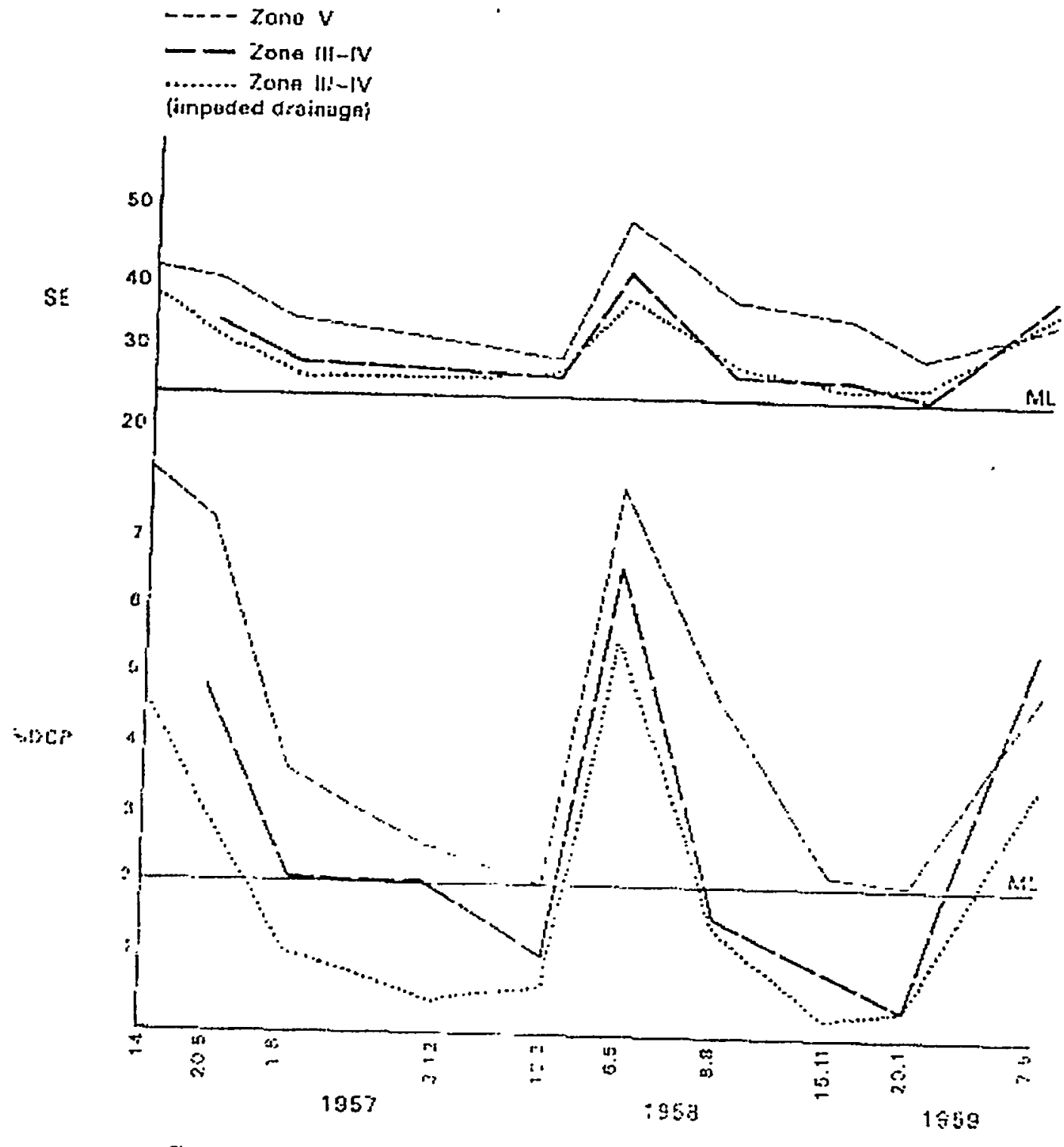

FIGURE 3.6: Average values of digestible crude protein (DCP) and starch equivalent (SE) of all grasses collected in three ecological regions in Karamoja District, Uganda, 1957-1959: ML= maintenance level (from Bredon and Wilson 1963).

\subsubsection{Conclusions}

- This calls for supplement feeding during the drier periods and manuring of the ground. In beef production, however, farmers would rather go for compensatory growth rather than supplement.

- Organic manuring of the soil would be enhanced if the nomadism culture is eliminated. 
- Increased ambient temperatures reduce forage quality and thereby decreasing animal production and this calls for a good farm management system. Growth and development of an animal reflects the climate and imposed management factors of its environment (Thornton D.D. 1960).

- The Major problem in beef production is to discover a system of management, which will maintain WET season quality of herbage for longer period of the year. Much work has been concerned with altering the environment by excluding fire and stocking at a destiny that should encourage lower growing species which are naturally higher in crude protein. This conclusion, however, has not considered effects of other environmental factors such as diseases and pests or that these were adequately controlled. 


\subsection{REFERENCES}

1) Bredon, RM. and Torrel, D.J. (1962). The chemical composition and nutritive value of common grasses in Uganda. part II. The comparison of chemical composition and nutritive value of grasses throughout the year, with special reference to later stages of growth. Trop. Africa. Trin, 39; pp. $13-17$.

2) Bredon, R.M. and Marshall, B.F. (1962). Nutrition of Zebu cattle in Uganda. Selective consumption by stall fed cattle and its influence on the results of a digestibility trial. E. Afric. for J., 27; pp. $168-172$.

3) Bredon, R.M. and Wilson, J.G. (1963). The chemical composition and nutritive value of grasses from the semi-arid area of Karamoja (Kotido, Moroto). E. Afric. agric. for J., 28 pp. $134-142$.

4) Marshall, B.F., Bredon, R.M. and Juko, C.. (1961). The nutrition of Zebu Cattle - Part IV. The intake of dry matter by cattle with some water on the digestibility of Rhodes grass and star grass Lays. J. Agric. Sci., 56; pp. 181 - 1960.

5) Thornton, D.D. (1960). Estimation of Ankole and Zebu Cattle weights by Girth measurement. E.A. Agricultural and forestry Journal, Vol. XXVI, No. 2 - October 1960.

6) Thornton, D.D. (1966). Some aspects of the nutritive value of Western region rangelands. Faculty of Agriculture, Senior Lecturer - Makerere University College, 10th March.

7) Thornton, D.D. (1968). Intensive domestic use of rangelands. East African Agricultural and Forestry Journal. Special issue,. Vol. XXXIII, June 1968. pp. 148.

8) Warrick, R.A. and Gifford, R. with Party, M.L. 1986 Carbon dioxide, de, Climate Change and Agriculture. In the Greenhouse Effect, Climate Change and Ecosystems, B. Blin, B.R. Doos, Jager and R.A. Warrick (Ends) Scope 29 Chichester, John Wiley and some, pp. $393-473$. 


\subsection{UGANDA'S V\&A ASSESSMENT FOR THE FORESTRY SECTOR}

Uganda is one of the countries participating in the U.S.-sponsored Climate Change Country Studies Program 1 . This report outlines the attempts made in the Forestry Sector to assess Uganda's Vulnerability and Adaptation (V\&A) to climate change using the standard methodologies developed by U.S.-Country Studies Program for all the participating countries worldwide. This methodology is based on the use of models, which predict the distribution of vegetation types and future forest growth under different climate conditions. While, this methodology has been proved to work in other countries, for Uganda, it was rather a failure as the predictions were found to be far from the realities on the ground. While there could be other reasons for this failure, lack of detailed country data seems to be the main cause.

Future efforts in assessing Uganda's Vulnerability and Adaptation to climate change should not only address this issue but also other alternative approaches not based on models should be tried as well. For example information from past events related to the extent and impact of abnormal weather fluctuations such as droughts and floods in the country could offer valuable information on how vulnerable Uganda is to climate change. Such information could then be used to develop adaptation strategies in the forestry sector in Uganda.

\subsection{Methods Used for the V\&A Assessment}

\subsubsection{Forest Ecosystem Models Used in the Assessment}

The required programs such as WINDOW, CLIM, HOLDR, GAP and GCMs such as GFDL, UKMO, etc. for the assessment of climate change for the forest sector were also provided on diskettes at the 1994 Honolulu, Hawii Workshop on V\&A.

\subsubsection{Procedure}

As a minimum requirement for the assessment of the impact of climate change on the Forest sector the Leemans and Cramer Global Data set compiled at the International Institute for applied Systems Analysis (LASSA), was recommended to be used. Therefore, the Africa Climate Data was extracted from this and was provided to each participant at the Workshop in Honolulu, Hawaii.

(i) The Climate Data for Uganda was extracted from the Africa Climate Data by running the WINDOW program in order to extract both the temperature and precipitation data.

U.S. Country Studies Program: Guidance for Vulnerability and Adaptation Assessment, 1994. 
(ii) Running the CLIM program using the input files of temperature and precipitation for Uganda in step (i) above. Thereafter calculation of the total precipitation and bio-temperature was done. This step generates output files for bio-temperature.

(iii) Using the HOLDR program and the bio-temperature from the above step, the Holdridge Life Zones for Uganda were calculated. The result is an output file, which is the predicted distribution of the vegetation or ecosystem based on the current climate data (variables of bio-temperature, mean annual precipitation and the ratio of PET to precipitation) was produced.

The output from the above step was then imported into a Geographical Information System (GIS) ARC-INFO software in a raster format ( $0.5 \square$ by $0.5 \square$ ). This was later vectorised and a map of the Holdridge life zones for Uganda was produced (see figure 4.1 below).

\subsubsection{Holdridge Life Model Results by Climate Change Scenario:}

Holdridge Life Zone Model Results by Climate Change Scenario. The vegetation of Uganda as predicted by the Holdridge model. 


\section{Holdridge Life Zones For Uganda}

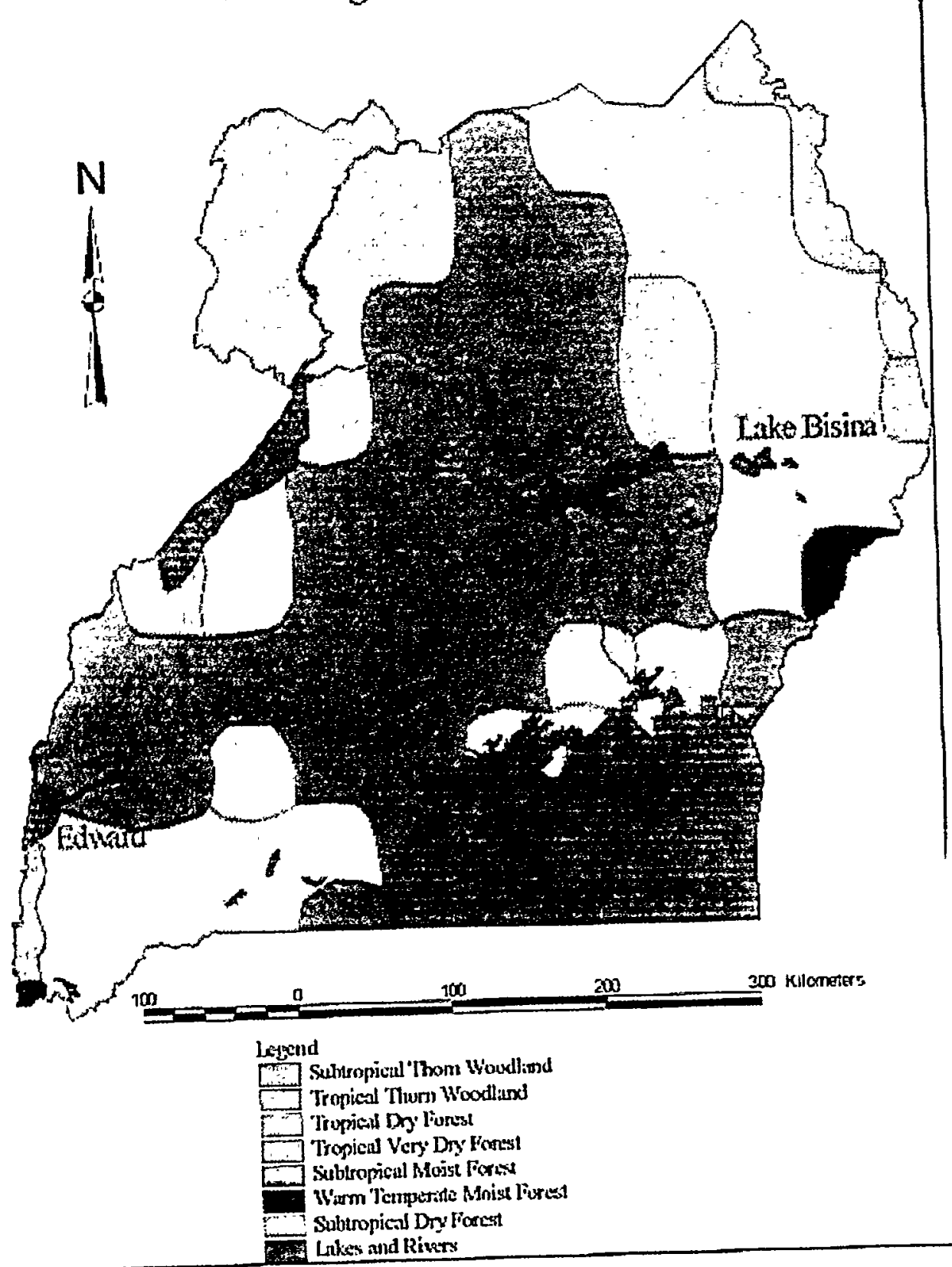

FIGURE 4.1 :HOLDRIDGE LIFE ZONE MODEL RESULTS BY CLIMATE CHANGE SCENARIO.

\subsection{Selection of Study Sites}

The geographic location for the study has been taken to be the whole of Uganda. However, had the initial results from the Holdridge model been encouraging, other site- 
specific locations were to be selected and focused on especially productive and or nature reserve forest regions.

\subsection{Results of the V\&A Assessment}

\subsubsection{Holdridge Life Zone Model Results by Climate Change Scenario}

The vegetation of Uganda as predicted by the Holdridge models was compared with the Vegetation of Uganda (produced by the Government of Uganda in 1964) in order to validate the vegetation of Uganda as predicted by the model. Generally, the predictions are either mixed up or completely off the reality on the ground in Uganda. The differences can also be recognized from the current land use/land cover map based on the results of the mapping by the National Bio-mass Study (1996) as shown in figure 4.2 below. 


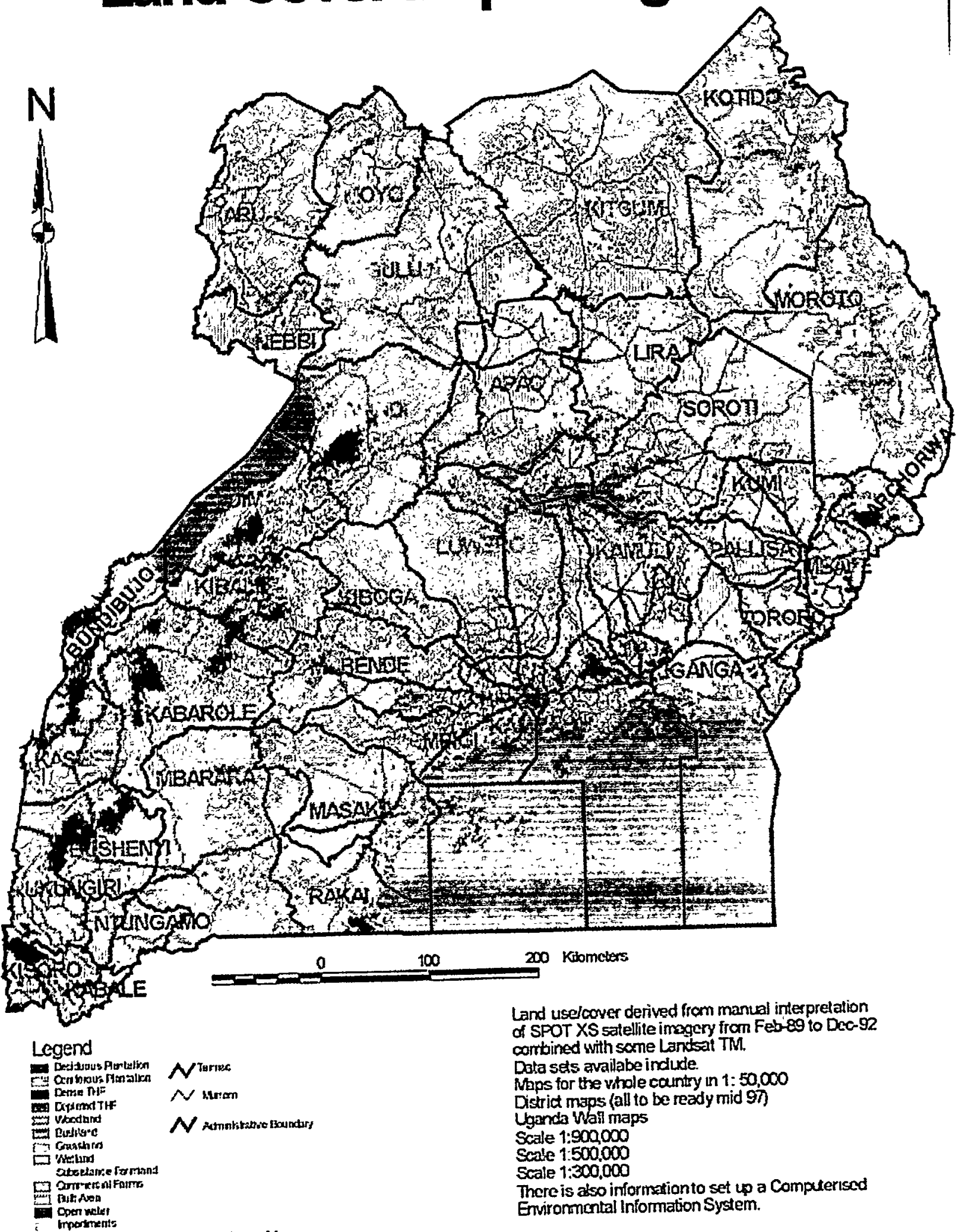

Procuced by

The Nutiond Eiomass Study, Forest Cepartment.

P.O. Box 1613, Kmpala.

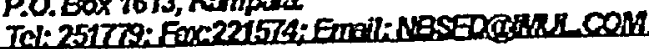

FIGURE 4.2: LAND USE/LAND COVER MAP OF UGANDA FROM THE BIO-MASS STUDY (1996) 


\subsubsection{Evaluation of Adaptation Policies Using V\&A Assessment Results}

Since the models were a failure in Uganda's case, evaluation of Adaptation Policies using the results from the V\&A assessment became a futile attempt. However, other alternatives of evaluation of adaptation to climate change are possible. For example past experiences from weather calamities such as droughts and floods could be used to develop adaptation strategies for Uganda. Because of long time periods required for tree growth, development of adaptation strategies in this sector shall be anticipatory rather than reactionary. Likely, options or opportunities, which are possible in Uganda, are forestation, conservation and protection of the existing forest estate.

\subsubsection{Forestation}

Forestation/Reforestation of hilly areas shall help control soil erosion as well as protect the watersheds of the region concerned. By planting an area originally without trees, such a strategy also means that the government shall be expanding its carbon stocks. During the growth of the trees carbon shall be sequestered by photosynthesis from the atmosphere. By this action Uganda shall be at the same time fulfilling its mitigation action/strategy obligations to member countries of the Conference of the Parties (COP). The options in the forestry sector, e.g. forestation/reforestation are appealing due to excellent tree growth requirements in Uganda.

This is killing two birds with one stone. The benefits of the forest ecosystem are as many as mentioned above. With the present government policy of Plant More Tree Campaigns this strategy is quite feasible with government policy and shall not cost any additional funds to implement it. The public awareness however about climate change and how to adapt should also be included in these campaigns. The choice of species for forestation are many, e.g. deciduous hard wood species such as Acacia spp., Combretum and Buteryspermum spp. which are drought resistant should be introduced in future forestation programs in the northern drought prone areas. These species growth characteristics are so slow and their economic importance are mainly for the production of quality charcoal and firewood and not timber. The commonest/plantation species though today are Eucalyptus (exotic), Maesopsis eminii, softwood species such as pines and cypress these species are well known for their excellent growth characteristics in Uganda. Eucalyptus spp. are good for fuel wood, poles as well as timber logs. For pole production, the rotation age ranges from two years to eight years depending on the end use, i.e. whether for building or utility poles like for electricity transmission. Whereas, Maesopsis spp. shall be purely for the production of saw logs after 25 years. It is, however, not possible to analyze scenarios of selection of exact species for plantain based on climate change scenarios due to lack of data. 


\subsubsection{Forest Protection and Conservation}

The Forest Department is in charge of approximately 1.2 million ha of forest reserves on gazetted land (representing $6 \%$ of the Land area). Of this 417 ha is Tropical High Forest, 720,000 ha woodland and 30,000 ha are plantations. The greatest threat to this estate has been encroachment of the estate due to agricultural expansion and the need to increase food production for the increasing population. As mentioned earlier, present knowledge of degradation of the forest ecosystem due to climate change is scanty and unreliable. Nevertheless, the benefits of forest conservation and protection of the forest ecosystems with its diverse species of flora and fauna is well known. Protection of watersheds has many benefits such as reduction of runoff, control of soil erosion, protection of rare species among others. Adaptation strategies in forest protection and conservation is therefore a very good anticipatory action to climate change, instead of waiting for the adverse effects of weather or climate changes in the future. Besides, conservation and protection of the forest estate has been one of the traditional policies of the Forest Department.

For example under the multiple-use forest management policy, twenty percent of all the natural forest estate is to be designated and managed as a strict nature reserve. This action is aimed at preserving Uganda's rich bio-diversity for the present and future generations. A further $40 \%$ of the estate will be designated primarily for the environmental protection (watersheds, etc.) and $50 \%$ will be managed for sustainable timber and other forest products. In this way Uganda expects to meet its obligations to the International Convention on Biological Diversity (IBCD) and as well as Intergovernmental Panel on Forest (IPF). The former ratified by Government of Uganda in September 1993.

Therefore, development of adaptation strategy to climate change is not a new idea to the FD. Only efforts to sensitize the public about the benefits that forests have as an adaptation to future climate change should be intensified. New approaches to protection, policing and punishment as has been the tradition of the FD should be discouraged. Instead, participatory approaches like Joint Management of the Forest Estate should be put in place. Fortunately, this new concept in natural resource management is well circulated among the foresters. What is left is to translate this concept into practical terms on the ground.

\subsection{Discussion and Conclusions}

The analysis for the Forest Sector for Uganda as it is now, is unreliable due to probably lack of proper climatic data or possibly too many generalizations. Until further improvements on the two models cited above are done and more data is collected, assessing vulnerability and adaptation on the recommended methodology shall not only be unreliable, but misleading. However, notwithstanding the shortcomings above, opportunities for developing adaptation strategies in Uganda do exist and it is possible to implement them if the public and the government are committed. 


\subsection{UGASUA'S V\&A ASSESSMENT FOR THE WATER RESOURCES SECTOR}

\subsection{Introduction}

Because $15 \%$ of Uganda's total area is covered by water it may seem, at national level, to be endowed with abundant water resources. It should, however, be noted that $80 \%$ of this area is covered by Lake Victoria. Therefore the distribution of the surface water resources in Uganda is not even and consequently large parts of Uganda especially in the North and South-West are semi-arid and hence face severe water shortages. Even in the areas with rivers and lakes the cyclic and persistent periods of drought have had adverse effects on the quantity and quality of water resources. Human activities such as deforestation and poor agricultural practices have had a big impact on both the quality and quantity of the available water resources. Some of these activities have been prompted by the struggle for the ever-diminishing arable land and water resources mainly due to unfavorable climate variability and increase in population. The spread of the water hyacinth and the discharge of untreated waste into the water bodies have lead to a further deterioration of the water quality.

Despite the fact that Uganda's available water resources can satisfy the national water demand now and in the near future, the temporal and spatial distribution of the resources is such that there will be competition for water in the dry areas during droughts where the streams are not perennial. Though currently irrigation is still practised on a very small scale, it is anticipated that with the increase in population the irrigation water demands are likely to increase substantially in future. This will further exert pressure on the limited surface water resources.

In most rural parts of Uganda, ground water is the main source of water and usually satisfies the domestic water demand. However, in densely populated areas ground water, even when supplemented with shallow wells and springs, may not meet supply requirements without significant cost implications. Therefore ground water may be considered not sufficient in the regional context.

The spatial variation of mean annual rainfall is very large over the country $(625 \mathrm{~mm}$ $2000 \mathrm{~mm}$ ) and depends both on the local topography and the distance from Lake Victoria. Heaviest rainfall is experienced in areas close to the lake and in mountainous areas. Two wet seasons are experienced all over the country except in the northern and south western regions. The seasonal pattern is linked to the double passage of the Inter Tropical Convergence Zone (ITCZ).

Although many rivers in the country are known to have very large flows during periods of high rainfall, only sparse information is available on frequent flooded areas. The large storage in swamps and the traditional acceptance of annual flooding of the swamp margins has undoubtedly influenced the perception of flooding. However, problems of flooding from flashy mountain streams on Mt. Elgon and Mt. Rwenzori have 
been reported. These instances include flooding of the lower valleys in Kilembe and the airfield by R. Nyamwamba, flooding of the lower areas of Mbale by River Manafwa, flooding of Mobuku irrigation rice scheme by R. Sebwe, flooding of several parts of Kampala city mainly due to poor drainage. In addition, severe erosional problems have been reported in Mt. Rwezori areas, hilly areas of Moyo and Arua, muddy rivers in the Mt. Elgon region and in Kigezi. Silting has been reported in the rivers in Kumi district and Lake Wamala. Lake Kyoga also has been reported to be rapidly silting up as a consequence of erosion in the Mr. Elgon areas. It is feared that siltation of the drainage path from the Eastern catchments may in the long run cause increased water logging and drainage problems upstream of the deposition reaches.

These problems are expected to become more frequent and severe with the impending climate change, hence the need for the V\&A assessment.

\subsection{Methods Used for the V\&A Assessment}

\subsubsection{Hydrologic and Water Resources Methodologies Used in the Assessment}

A number of models have been developed or modified for studying the potential impact of climate change on water resources. However, these models use different approaches and assumptions leading to different conclusions. Furthermore, most of these models take effective rainfall and potential evapotranspiration as input; leading to difficulty in find a consistent method/criteria for estimating them. More sophisticated distributed models (e.g. STANFORD IV and SACRAMENTO) developed for short-term forecasts have been applied for climate change studies but they are not advantageous due to over parameterization and hence calibration procedures.

For the above reasons, the Wat Bal model which uses five parameters and combines both the water balance and potential evapotransipiration sub-components was selected as appropriate for climate impact assessment on river basin runoff under the U.S. Country Studies Program. This is a lumped model that makes use of small number of parameters to describe water movement into and out of a conceptualized basin; and incorporates both a water balance and potential evapotransipiration components. The five parameters are related to direct runoff, sub-surface runoff, surface runoff, maximum catchment water-bolding capacity; and base flow. Potential evapotransipiration is modeled using the Priestly-Taylor method with net radiation and albedo component.

Inputs to the model include time series of rainfall, runoff and temperature. Monthly mean relative humidity $(\%)$ and bright sunshine hours per day are required for computation of net radiation.

\subsubsection{Selection of Study Sites}

Three study sites have been selected to assessment the impact of potential climate change on water resources in Uganda. They were intended to represent the range of 
climatic variations by selecting a catchment in each of the major climate zones in Uganda: humid, moist-sub-humid and dry sub-humid zones. Due to lack of reliable runoff data it was not possible to select a catchment in the semi-arid zone. The historic data was broken into two segments, one was used for calibration and the other for validation.

- Tochi I River Basin with an area of $671 \mathrm{~km}^{2}$ is in Northern Uganda at latitude

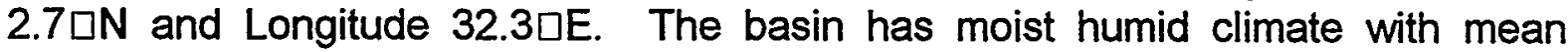
annual air temperature of approximately $200 \mathrm{C}$; mean annual rainfall $1110 \mathrm{~mm}$; and potential evapotransipiration $1732 \mathrm{~mm}$. The region is characterized by dense ground cover of $70 \%$ broad leafed forests and $30 \%$ perennial grass (Gibb, 1989). The overall runoff co-efficient is approximately $11 \%$.

- River Sezibwa at Falls with catchment area of $175 \mathrm{~km}^{2}$ is in southern Uganda lying between Longitude 32.52םE and Latitude $0^{\prime} 22 \mathrm{DN}$. The basin has humid climate and ground cover is about $100 \%$ broad-leafed forests.

- River Ruizi at Mbarara with catchment area of $2070 \mathrm{~km}^{2}$ in dry-sub-humid climate. The location is at Lat $037 \mathrm{~S}$ and Long $3039 \mathrm{E}$. Ground cover is estimated at $75 \%$ grass and $25 \%$ bare soil.

The rainfall records used for the river basins spans the years $1951-1980$; temperature record is from 1960 - 1980; and runoff record is from 1954 - 1980 for River Ruizi; 1970 -1978 for Sezibwa and from $1952-1980$ for Tochi I. The records have several gaps. Due to the gaps in the runoff record, the model was calibrated over the continuous three years record of data and validated over yet another not consecutive record.

\subsubsection{Methodology for Economic Analyses}

To establish static direct sectoral impacts, both current and future water use in the following sectors was estimated assuming present levels of growth rates and consumption levels:

- rural domestic water supply;

- urban and industrial water supply;

- agricultural water supply; and

- livestock water supply

Comparison of the projected demand and supply in all the sectors indicated that the baseline renewable water supply of 39.45 million $\mathrm{m}^{3} / y e a r$ was sufficient to meet the projected demand assuming the down stream countries do not abstract significant amounts of water from River Nile. This assumption may only remain valid if a mechanism is devised for equitable sharing of the Nile waters. An economic value of each of these activities was estimated for the base year 2075 . Increases and decreases in the water resources supply were equally allocated to each sector and the resulting changes in each sector estimated. 


\subsection{Adaptation Alternatives Evaluated Using the Methodologies}

Future projections of demand and supply in the different sectors indicated that the aggregate water supply at national level was adequate to meet the demand. This did not take into consideration the spatial variability especially were shortages already occur due to lack of data.

Two scenarios were considered:

- One in which Uganda would be free to utilize the water resources with in its territory without taking into consideration the interests of the downstream countries in which case the projected aggregate demand would be satisfied without developing alternative sources; and

- where the interests of the downstream countries are considered and assuming these will abstract significant amount of water from the Nile. In this case the aggregate demand would not be satisfied and alternative options like increase in water supply by using alternative sources, reduction in demand by using conservation measures would have to be used.

\subsection{Results of the V\&A Assessment}

\subsubsection{Results of the Hydrologic Vulnerability Assessment}

Scenario development for climate change impact assessment was based on hypothetical scenarios for River Tochi and GCM based scenarios for all the three catchments.

i) Hypothetical Climate Change Scenarios: Tochi I

Put in the framework of sensitivity analysis by applying an ensemble of potential climates. The ten climate change scenarios are shown in the Tables below. The basin runoff shows strong response to moderate change in rainfall and temperature. Temperature is negatively correlated to runoff while rainfall, not surprisingly, is positively correlated. These reveal the sensitivity of the basin to rainfall change where a twenty-percent increase or decrease in rainfall leads to over a $35 \%$ increase or decrease in runoff. Approximately $12 \%$ decrease in runoff is observed for each $\square C$ increases in temperature. 


\begin{tabular}{|l|l|l|l|l|l||}
\hline \hline TABLE 5A: & $\begin{array}{l}\text { CHANGE IN RIVER TOCHI I RUNOFF UNDER BYPOTHETICAL } \\
\text { CLIMATE CHANGE SCENARIOS }\end{array}$ \\
\hline & PO & P10 & P20 & P-20 & P-20 \\
\hline T0 & $0 \%$ & $23 \%$ & $47 \%$ & $-19 \%$ & -37 \\
\hline T2 & $-10 \%$ & $10 \%$ & $31 \%$ & $-28 \%$ & $-44 \%$ \\
\hline T4 & $-22 \%$ & $-5 \%$ & $4 \%$ & $-37 \%$ & $-51 \%$ \\
\hline
\end{tabular}

ii) GCM Based Scenarios

The results of the impact of GCM based estimates of climate change on runoff for each of the three catchments and the extrapolation for the whole of Uganda is shown in Tables 2.1 to 2.4. Apart from the CCM model the other three models predict on the average $10-20 \%$ increase in runoff under future climate change scenario.

Table 5 B.1__Hydrologic Vulnerability Assessment for River Ruizi at Mbarara

\begin{tabular}{||l|l|l|l|l||}
\hline & $\begin{array}{l}\text { Percent inge in } \\
\text { Change } \\
\text { Precipitation }\end{array}$ & $\begin{array}{l}\text { Change in } \\
\text { Temperature } \\
\text { (口C) }\end{array}$ & $\begin{array}{l}\text { Percent } \\
\text { Change in } \\
\text { Runoff }\end{array}$ & $\begin{array}{l}\text { Ratio of Annual } \\
\text { Storage Capacity } \\
\text { to Annual Runoff }\end{array}$ \\
\hline \hline CCM & -10 & 2.3 & -13 & N.A. \\
\hline GFD3 & 20 & 2.6 & 22 & N.A. \\
\hline UK89 & 10 & 3.5 & 4.9 & N.A. \\
\hline GISS & 30 & 3.6 & 15 & N.A. \\
\hline
\end{tabular}

Table 5 B. 2 Hydrologic Vulnerability Assessment for River Sezibwa at Falls

\begin{tabular}{|l|l|l|l|l||}
\hline & $\begin{array}{l}\text { Percent change } \\
\text { in Precipitation }\end{array}$ & $\begin{array}{l}\text { Change in } \\
\text { Temperature } \\
(\mathrm{CC})\end{array}$ & $\begin{array}{l}\text { Percent Change } \\
\text { in Runoff }\end{array}$ & $\begin{array}{l}\text { Ratio of Annual } \\
\text { Storage } \\
\text { Capacity to } \\
\text { Annual Runoff }\end{array}$ \\
\hline CCM & 0 & 2.3 & -1.5 & N.A. \\
\hline GFD3 & 20 & 2.7 & 19 & N.A. \\
\hline UK89 & 10 & 3.6 & 12 & N.A. \\
\hline GISS & 20 & 3.7 & 16 & N.A. \\
\hline
\end{tabular}


Table 5 B.3: Hydrologic Vulnerability Assessment for River Tochi I

\begin{tabular}{|l|l|l|l|l||}
\hline & $\begin{array}{l}\text { Percent change } \\
\text { in Precipitation }\end{array}$ & $\begin{array}{c}\text { Change in } \\
\text { Temperature } \\
(\square \mathrm{C})\end{array}$ & $\begin{array}{l}\text { Percent Change } \\
\text { in Runoff }\end{array}$ & $\begin{array}{l}\text { Ratio of Annual } \\
\text { Storages } \\
\text { Capacity to } \\
\text { Annual Runoff }\end{array}$ \\
\hline CCM & 0 & 2.4 & -22 & N.A. \\
\hline GFD3 & 20 & 2.5 & 18 & N.A. \\
\hline UK89 & 20 & 3.4 & 15 & N.A. \\
\hline GISS & 20 & 3.7 & 12 & N.A. \\
\hline
\end{tabular}

Table 5 B.4 Hydrologic Vulnerability Assessment for Uganda

\begin{tabular}{|l|l|l|l|l||}
\hline & $\begin{array}{l}\text { Percent change } \\
\text { in Precipitation }\end{array}$ & $\begin{array}{l}\text { Change in } \\
\text { Temperature } \\
(\square \mathrm{C})\end{array}$ & $\begin{array}{l}\text { Percent Change } \\
\text { in Runoff }\end{array}$ & $\begin{array}{l}\text { Ratio of Annual } \\
\text { Storages } \\
\text { Capacity to } \\
\text { Annual Runoff }\end{array}$ \\
\hline CCM & -3.3 & 2.3 & -12.2 & N.A. \\
\hline GFD3 & 20 & 2.6 & 19.7 & N.A. \\
\hline UK89 & 13.3 & 3.5 & 10.6 & N.A. \\
\hline GISS & 23.3 & 3.7 & 14.3 & N.A. \\
\hline
\end{tabular}

\subsubsection{Results of Water Resources Supply and Demand Models by Climate Change Scenario}

The future projections of urban, rural domestic and livestock water demand were based 1991 data projected assuming present levels of growth rates and consumption levels. Industries are generally connected to urban water supply networks and no attempt has been made to estimate their water demand separately but an allowance has been made in the future demand for urban dwellers to include industrial demand. Water demand for irrigation are based on FAO estimates (1987). The FAO estimates are based on what is technically feasible rather than the economic and social feasibility of large scale irrigated agriculture in Uganda. However, the estimates are believed to represent the ultimate water demand for two growing season per year under the 2075 scenario. The irrigation demand is combined with livestock water demand to give the agricultural water use.

The baseline renewable water supply of 39.45 billion $\mathrm{m}^{3} / y e a r$ represents the outflow of the Nile and River Aswa (the two drainage outlets of the whole of Uganda) including the 
inflows from upstream countries. In a future situation these countries will abstract significant water from the Nile which has not been taken into account. Similarly, the water demand of the downstream countries (which have an interest in uninterrupted flow of the Nile) has not been taken into account. The Equatorial Lakes (Victoria, Kyoga and Albert) are natural reservoirs with no century storage. The storage in this lakes is not considered a renewable supply. The results of the supply and demand comparison is shown in Table 3. Under this scenario the aggregate water supply at national level is adequate to meet the demand. This does not take into account spatial distribution were shortages already occur, especially in the semi-arid regions in the north, north-east and southwest. GCM models predict increase in the available supply.

On the other hand, in the absence of agreement in the Nile basin on sharing of the water resources and regulation of the lakes, if we assume that the only available water to Uganda is the runoff generated within her territory (estimated at 14 billion m3/year) then supply will not be able to meet demand under the baseline conditions. Under the GDF3 prediction this supply will increase to the same level as demand.

Table 5 C: Water Resource Supply and Demand in Year 2075 in $\left(10^{9} \mathrm{~m}^{3} / \mathrm{yr}.\right)$ Estimated Using GFD $^{3}$ Model

\begin{tabular}{||l|l|l|l|l||}
\hline & Baseline & \multicolumn{1}{|c|}{$\underline{\underline{P}}_{10}$} & \multicolumn{1}{c|}{$\underline{\underline{P}}_{20}$} & \multicolumn{1}{c||}{$\underline{\underline{1}}_{16}$} \\
\hline Total Water Supply & 39.45 & 46.95 & 44.19 & 45.76 \\
\hline Total Water Demand & 16.87 & 16.87 & 16.87 & 16.87 \\
\hline Industrial Water Use & 1.72 & 1.72 & 1.72 & 1.72 \\
\hline Energy-related Water Use & .47 & .47 & .47 & .47 \\
\hline Agricultural Water Use & 13.48 & 13.48 & 13.48 & 13.48 \\
\hline Domestic Water Use & 1.30 & 1.30 & 1.30 & 1.30 \\
\hline
\end{tabular}




\subsection{Evaluation of Adaptation Policies Using V\&A Assessment Results}

\begin{tabular}{|c|c|c|}
\hline Strategy Type & Practice Change & Government Action \\
\hline Water Conservation & $\begin{array}{l}\text { Recycling of water (water re-use) } \\
\text { Reduction in water demand }\end{array}$ & $\begin{array}{l}\text { strict implementation of the } \\
\text { Water Statute }\end{array}$ \\
\hline Pollution Control & $\begin{array}{l}\text { Improved sanitation } \\
\text { Strict waste management } \\
\text { Use of better soil conservation } \\
\text { methods to minimize erosion }\end{array}$ & $\begin{array}{l}\text { Routine water quality } \\
\text { monitoring } \\
\text { emphasis on the polluter } \\
\text { pays' principle }\end{array}$ \\
\hline $\begin{array}{l}\text { Construction of Storage } \\
\text { structures }\end{array}$ & $\begin{array}{l}\text { Development of new dam sites } \\
\text { Land leasing in potential dam sites } \\
\text { for easy vacation when need arises }\end{array}$ & $\begin{array}{l}\text { Restriction on development } \\
\text { in potential dam sites }\end{array}$ \\
\hline River Basin Planning & $\begin{array}{l}\text { Conjunctive use of surface and } \\
\text { ground water }\end{array}$ & $\begin{array}{l}\text { Emphasis on integrated } \\
\text { river basin management }\end{array}$ \\
\hline $\begin{array}{l}\text { No change in current } \\
\text { practice }\end{array}$ & No change & No action \\
\hline
\end{tabular}

\subsection{Evaluation of Adaptation against Multiple Criteria}

\begin{tabular}{|l|l|l|l|l|l||}
\hline & $\begin{array}{c}\text { No Policy } \\
\text { Action }\end{array}$ & $\begin{array}{c}\text { Water } \\
\text { Conservation }\end{array}$ & $\begin{array}{c}\text { Pollution } \\
\text { Control }\end{array}$ & $\begin{array}{c}\text { New Storage } \\
\text { Structures }\end{array}$ & $\begin{array}{c}\text { River Basin } \\
\text { Planning }\end{array}$ \\
\hline Short-term cost & Excellent & Good & Fair & Poor & Fair \\
\hline Long-term cost & Poor & Good & Good & Good & Good \\
\hline Effectiveness & Poor & Good & Good & Good & Good \\
\hline Feasibility & Excellent & Fair & Good & Fair & Fair \\
\hline Distributed Impacts & Poor & Good & Good & Good & Good \\
\hline
\end{tabular}

\subsection{Discussion and Conclusions}

Results of the hydrological vulnerability assessment using three river basins, i.e. Tochi, Sezibwa at falls and Ruizi at Mbarara, generally indicated a $10 \%-20 \%$ increase in runoff for most of the country. However, this may not be the case with the semi-arid areas where the runoff may instead reduce. It was not possible to justify this reduction due to lack of sufficient data for any catchment in the sami-arid zone.

The future projections of urban and rural water supply indicated that the aggregate water supply at national level would be adequate to meet the demand. However, this did not take into consideration the spatial and temporal distribution of the water. It is anticipated that water demand may not be met in the semi-arid regions of north, northeast and south-west of Uganda, where shortages already occur, unless alternative water sources are developed. 
Since most of Uganda's water resources are shared with other countries, increased abstraction by the downstream countries and the absence of a cooperative framework for equitable sharing of the resources are likely to lead to severe water shortages in future. This is more so with increase use of water for supplementary irrigation. It is therefore important that steps are now to avert any future catastrophes. This may be in the form of implementing various adaptation options like integrated watershed management, pollution control, conjunctive use of both surface and ground water, development of new potential sources of water supply and storage facilities and practicing improved soil and water conservation measures. 


\subsection{MITIGATION OPTIONS ASSESSMENT FOR THE ENERGY SECTOR}

\subsection{Introduction}

\subsubsection{Geography}

Uganda is a small land-locked country, which shares borders with Kenya to the East, Sudan to the North, Zaire to the West, Rwanda to the South/West and Tanzania to the South. Its location is astride the equator, which extends from $1.5^{\circ} \mathrm{S}$ to $4^{\circ} \mathrm{N}$. The total area of Uganda is 241,038 sq. $\mathrm{km}$ of which 197,096 sq. $\mathrm{km}$ is land and 43,942 sq. $\mathrm{km}$ is water and swamps.

\subsubsection{Population}

According to the 1991 population census, the country has 16.7 million people (with a multiplicity of tribes) and is estimated to be growing at rate of $2.5 \%$ per annum. $88.7 \%$ are rural dwellers while $11.3 \%$ are urbanites. The average life expectancy is 47 years and the illiteracy rate is $65 \%$ and $52 \%$ for female and male respectively.

\subsubsection{Economic Structure}

Uganda's economy runs on basically two sectors, i.e. the agricultural and industrial sectors.

\subsubsection{Agricultural Sector}

Uganda is a developing country and it heavily depends on the agricultural products both for consumption and export. $84.8 \%$ of the dryland is arable although only $29.9 \%$ of this is used for agricultural purposes. The main cash crops which bring in foreign exchange are: coffee, cotton, tea and tobacco. During the political turmoil of between 1971 to 1986, the activities were very minimal and Uganda's economy slumped tremendously. Since then, the agricultural sector has been diversified by encouraging, in addition to the traditional export crops, the export of other agricultural crops. In addition, the monopoly of export of crops has been broken by allowing individual farmers/traders to export crops like fruits and flowers. Marketing activities are largely handled by the private sector.

\subsubsection{Industrial Sector}

The Industrial Sector ground to a near halt during the instability of the economy. Many industries were mismanaged and as a result the contribution from the industrial sector to the economic development of the country became insignificant. In addition, Uganda strong economic ties with Kenya and Tanzania broke up in 1977. This state of affairs ushered in the economic inflation, which bedevilled the economy for over 20 years. Consequently, the Uganda shilling had to be devalued many times. Between 1987 to-date, Government has embarked on a recovery programme of the whole economy. It has liberalised most of the sectors. This programme inter-alia has prompted the adoption of a market oriented 
development strategy, lifting of exchange control regulations, import liberalisation, exchange price incentive for farmers, divestiture of ailing public enterprises and creating a conducive climate for the private sector investment. All this has been done to enhance the economy.

The infrastructure has also been strengthened. About $2000 \mathrm{~km}$ is tarmac and $8000 \mathrm{~km}$ is murram. In addition, there is a railway source, which traverses Uganda in the Southern belt from East to West and another branch from the East to North.

As a result of all these developments, in 1990, the Gross Domestic Product (GDP) was shs. 254.3 billion with an annual growth rate of 4.3\%. The per capital GDP was shs. 94,000 billion with a growth rate of $1.5 \%$ per annum. This marked a significant economic growth in the Uganda economy.

\subsubsection{GHG Mitigation Analysis}

This report analyses the mitigation options for energy related greenhouse gas emissions in Uganda for the period 1990 to 2020. In the analysis, the base case energy demand and supply situation is presented and using the energy model, Long Range Energy Alternatives Planning (LEAP) and the official base case energy demand forecasts, the GHG emissions over the study period is presented. The LEAP energy model is further used to analyses the mitigation options identified by the study.

\subsection{Energy Sector Overview}

95\% of energy consumption in Uganda in 1990 was derived from biomass energy resources. If the biomass resources were to be used on a sustainable basis, this consumption area would effectively not contribute GHG emissions since carbon emitted would be balanced by carbon sequestered during biomass growth. The stainable use of biomass based fuels will be ensured if the following actions are promoted:

(i) Afforestation

Afforestation/reforestation of hilly areas shall help control soil erosion, protect watersheds and expand the carbon stock.

(ii) Forest Protection and Conservation

The greatest threats to the forestry areas protected by Government has been encroachment for agricultural expansion and fuel wood harvesting. If this encroachment is controlled, the forest resources can be used in a sustainable manner. The sustainability of biomass energy use in Uganda is discussed in detail under the Chapter on the Forestry (non-energy) Sector. 
The remaining $5 \%$ of energy consumption in 1990 , representing $11.28 \mathrm{PJ}$ is accounted for by electricity (1.15PJ) and petroleum products (10.13 PJ). Almost all of the electricity is generated from hydropower. Therefore, electricity production and consumption does not contribute to GHG emissions. Due to the great potential for hydropower development, which is relatively cheap by world standards, the situation is bound to remain the same for years to come.

Increased electrification offers an opportunity for GHG mitigation where electricity replaces use of fossil fuels like kerosene for rural lighting, diesel in small-scale agro-based industries, and residual/fuel oil in industries. Increased electrification rate based on grid extension can be supplemented by small-scale hydropower development and solar pv systems.

Almost $80 \%$ of the fossil fuel use is accounted for by road transport. Rational use of energy in the road transport sector, therefore, can significantly contribute to reduction of GHG emissions in Uganda. This would include efficient use of fossil fuels arising from reduction of traffic congestion, proper maintenance of roads and proper maintenance of vehicles. Another option is substitution of petrol by ethanol derived from biomass resources such ethanol would be blended with petrol.

\subsection{Methodology and Data}

The residential, commercial, industrial and transport sectors are used in the assessment. In the residential sector, the following break-down is used: Urban electrified, urban nonelectrified, rural electrified and rural non-electrified. In the commercial and industry sectors, the breakdown is by fuel. In the transport sector, the breakdown is by road, rail, water and air.

The available data are not sufficiently disaggregated. In the residential sector, for example, data are available according to the number of households electrified or non-electrified for both the rural and urban areas. The respective electricity consumption rates can then only be estimated based on assumptions derived from the mature of electricity usage in urban areas compared to rural areas. Another example of problems of data disaggregation is for diesel use. While the total amount of diesel consumed in a given year, it cannot be established how much of this was used in the transport sector compared to how much was used in the industry, commercial and residential sectors. This can only be estimated.

\section{Data}

The initial input data were obtained from the Government Ministries responsible for energy, finance, planning and economic development, Trade and Industry as well as Transport and Communications. The primary data on energy used are quite reliable. Uncertainties, however, are due to the assumptions made during the disaggregation of the data. Another problem area is that cost data is not readily available. For the purposes of this study therefore only a qualitative analysis of the cost of emission abatement was taken. 
After making the necessary assumption and estimates for disaggregation of data, the model "Long Range Energy Alternatives Planning" (LEAP) was used to compute GHG emissions for the various mitigation scenarios based on standard emission rates built in the model.

\section{Scenarios}

Five scenarios have been analysed: Base case and four mitigation options.

\section{Mitigation 1, (M1)}

Petrol ethanol blending with to a level of $15 \%$ for all petrol by the year 2020 (Ethanol blended with petrol up to a level of $20 \%$ would not require modification of the petrol engine. For this analysis, $15 \%$ blending is selected to ensure operation well within the recommended blending ratio).

\section{Mitigation 2, (M2)}

Reduction of traffic congestion on all roads by:

- $\quad$ ensuring proper road maintenance;

- improvement of road infrastructure to cater for pedestrians and other non-motorised transport;

- $\quad$ proper vehicle maintenance;

- $\quad$ installation of proper road signals; and

- $\quad$ development and implementation of policies and fiscal incentives to encourage mass public transport as opposed to use of small private cars.

Based on the results of a survey carried out in 1991, the analysis has assumed that reduction of congestion would lead to fuel savings of approximately $5 \%$.

\section{Mitigation 3, (M3)}

Development and implementation of an enhanced rural electrification programme to improve the electrification rate from the current $5 \%$ to $90 \%$ by the year 2020 . This will reduce dependence on kerosene for lighting in the residential sector.

The electrification strategy would be a combination of grid extension, development of small-scale hydropower in areas remote from the national grid and use of solar photovoltaic systems. 


\section{Mitigation 4, (M4)}

Elimination of use of residual/fuel oil in industries by replacement with hydro-based grid power. Analysis is based on the ideal assumption that complete elimination of residual/fuel oil is realised by the year 2020 .

\subsection{Results}

6.4.1 The Results from the study are summarised in Tables $6 \mathrm{~A}$ to $6 \mathrm{G}$ below. For the conversion from carbon content to carbon-dioxide released, a conversion ratio of $\mathrm{CO}: \mathrm{C}=44: 12$ was used.

\begin{tabular}{||l|c|c|c|c||}
\hline \multicolumn{5}{|c|}{ TABLE 6A } \\
\hline \multicolumn{5}{|c|}{ BASE CASE ENERGY DEMAND: FUEL BY YEAR, ALL SECTORS (KT) } \\
\hline \multicolumn{1}{|c|}{ Description } & $\mathbf{1 9 9 0}$ & $\mathbf{2 0 0 0}$ & $\mathbf{2 0 1 0}$ & $\mathbf{2 0 2 0}$ \\
\hline Electricity & 1.15 & 2.51 & 4.44 & 6.74 \\
\hline Gasoline & 3.49 & 7.33 & 11.94 & 19.46 \\
\hline Kerosene/Jetfuel & 1.74 & 2.20 & 2.80 & 3.25 \\
\hline Diesel/Gas Oil & 4.35 & 8.44 & 13.37 & 21.30 \\
\hline Residual/Fuel Oil & 0.55 & 1.16 & 1.90 & 3.09 \\
\hline Firewood & 170.27 & 251.06 & 341.59 & 459.78 \\
\hline Charcoal & 9.21 & 18.73 & 33.58 & 65.03 \\
\hline Vegetable Wastes & 21.16 & 27.19 & 33.41 & 38.90 \\
\hline Total & 211.93 & 318.63 & 443.03 & 619.56 \\
\hline CO $_{2}$ & 777.08 & $1,168.31$ & $1,624.44$ & $2,271.72$ \\
\hline
\end{tabular}




\begin{tabular}{|c|c|c|c|c|}
\hline (8YY uo!II!) $z 2 \cdot \varepsilon 6$ & $99^{\circ} \mathrm{ZS}$ & $Z Z \cdot I \varepsilon$ & $09^{\circ} \mathrm{SI}$ & 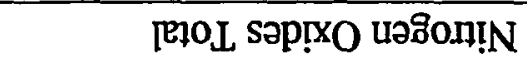 \\
\hline (ฮิx puesnoụ) LL'L06 & $8 S^{\circ} 96 \varsigma$ & $9 t^{\circ} 06 \varepsilon$ & $66.88 I$ & วนеपәW \\
\hline 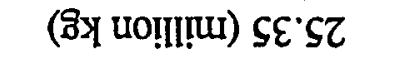 & $\varepsilon 6.9 I$ & $t 6^{\circ} 0 \mathrm{I}$ & IZ.9 & 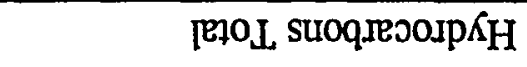 \\
\hline 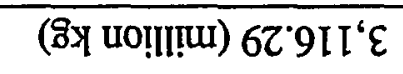 & $\angle \varepsilon^{\prime} \angle 9 I^{\prime} Z$ & $\angle t^{\circ}\left[9 S^{6} I\right.$ & $9 L^{\circ} S L 0^{6} I$ & 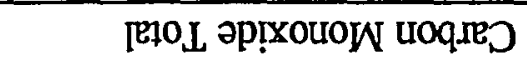 \\
\hline 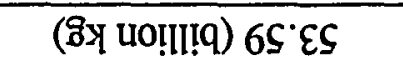 & {$[9.8 \mathcal{E}$} & $\varepsilon 6{ }^{\circ} L Z$ & $\varepsilon L \cdot 8 I$ & 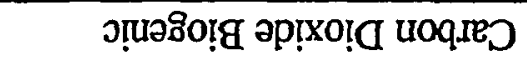 \\
\hline 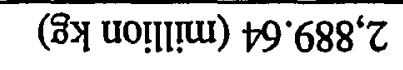 & $6 S^{\circ} 006^{6} \mathrm{I}$ & $89^{\circ} 9 t Z^{6} I$ & $09^{\circ} \mathcal{L} L 9$ & 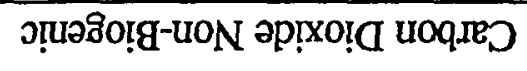 \\
\hline $0 z 0 Z$ & OLOZ & 0002 & $066 I$ & SNOISSIWG UIV \\
\hline \multicolumn{5}{|c|}{ 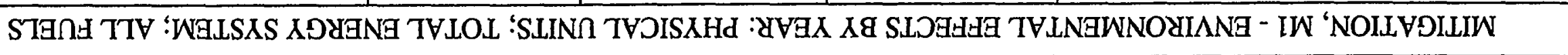 } \\
\hline \multicolumn{5}{|c|}{ ว9 ЯTRVL } \\
\hline
\end{tabular}

\begin{tabular}{|c|c|c|c|c|}
\hline (8्र uo!ll!w) tक & $\varepsilon 0^{\circ} \mathcal{E S}$ & $Z Z^{\circ} I \varepsilon$ & $09^{\circ} \subseteq I$ & 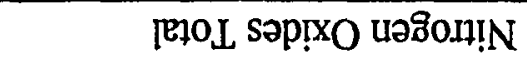 \\
\hline (8y puresnoyt) EI'SZO'I & $09^{\circ}$ Z६9 & $9 b^{\circ} 06 \varepsilon$ & $66 \cdot 88 \mathrm{I}$ & วนеपाวW \\
\hline 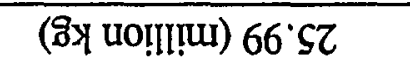 & $\varepsilon I \cdot L I$ & $t 60^{\circ} 0 \mathrm{I}$ & IZ'9 & 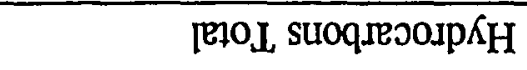 \\
\hline (8) uo!ll!u) $88^{\circ} 9 \mathrm{bI}^{\circ} \varepsilon$ & $\angle 0^{\circ} L L I^{\prime} Z$ & $\angle t^{\prime}\left[9 S^{6} I\right.$ & $9 L^{\circ} S L 0^{6} I$ & [EIOL әp!xOUOW UOQIED \\
\hline (อิY uo!ll!! $6 S^{\circ} \varepsilon S$ & {$[9 \cdot 8 \mathcal{E}$} & $\varepsilon 6: L Z$ & $\varepsilon L^{\prime} 8 \mathrm{I}$ & 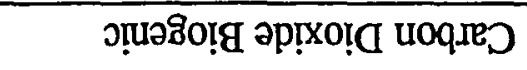 \\
\hline 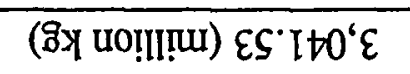 & $28^{\circ} \angle D 6^{6} I$ & $89^{\circ} 9 \nabla \tau^{6} I$ & $09^{\circ} \varepsilon L 9$ & 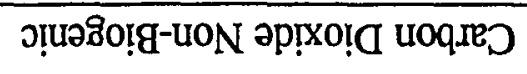 \\
\hline 0202 & oroZ & 0002 & 066I & SNOISSIWG YIV \\
\hline \multicolumn{5}{|c|}{ 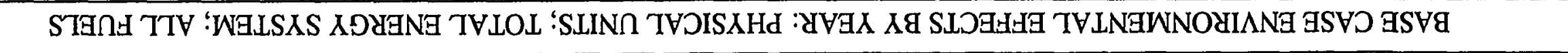 } \\
\hline \multicolumn{5}{|c|}{ 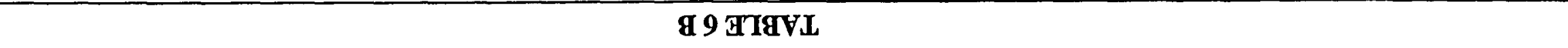 } \\
\hline
\end{tabular}




\begin{tabular}{|c|c|c|c|c|}
\hline 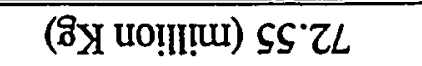 & $90 \% 97$ & $\varepsilon Z \cdot 6 Z$ & $09^{\circ} \mathrm{SI}$ & [Eం] Səp!x \\
\hline (8x pursnoul) $\mathrm{SS}^{\circ} 6 \mathrm{IO} 0^{6} \mathrm{I}$ & $\varepsilon 2 \cdot 629$ & $\varepsilon Z^{\circ} 68 \varepsilon$ & $6688 I$ & วนецाәW \\
\hline (8ิx uo!I!Iu) $6 I^{\circ} \hbar z$ & $06^{\circ} \mathrm{SI}$ & $\varepsilon L^{\prime} O I$ & {$[2 \cdot 9$} & 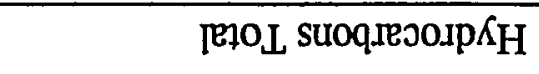 \\
\hline 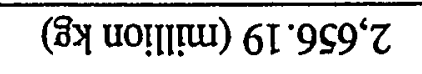 & ES $696^{\prime} I$ & $08^{\circ} 28 t^{6} I$ & $9 L^{\circ} S \angle 0^{6} I$ & 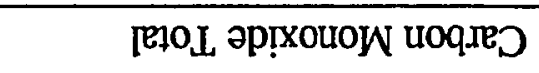 \\
\hline (8ิY UO!II!̣) $\nabla L^{\circ} \varepsilon S$ & $\mathcal{E I} 8 \mathcal{E}$ & $\angle S^{\prime} \angle Z$ & $\mathcal{E} L \cdot 8 \mathrm{I}$ & 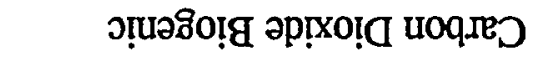 \\
\hline 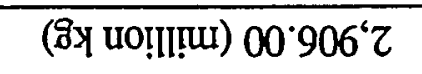 & $\varepsilon 9^{\circ} \hbar 98^{6} I$ & $\varepsilon b^{\circ} 9\left[Z^{\prime} I\right.$ & $09^{\circ} \varepsilon \angle 9$ & 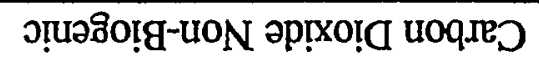 \\
\hline 0202 & 0I0Z & 0002 & 066I & SNOISSIKG YIV \\
\hline \multicolumn{5}{|c|}{ 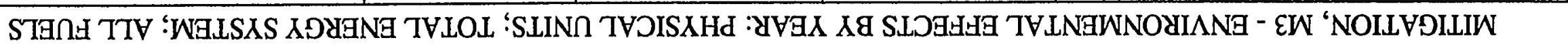 } \\
\hline \multicolumn{5}{|c|}{ 苟早TgVI } \\
\hline
\end{tabular}

\begin{tabular}{|c|c|c|c|c|}
\hline 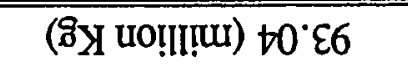 & $\angle I Z S$ & $69^{\circ} 0 \varepsilon$ & $09^{\circ} \mathrm{SI}$ & 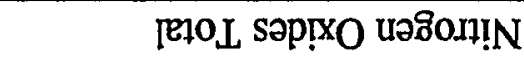 \\
\hline (8y puresnoup) $Z \angle \cdot 9 \angle 6$ & $88 \cdot 209$ & 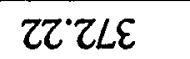 & $66 \cdot 88 \mathrm{I}$ & วนRนโәW \\
\hline (8y uo!ll!w) $\angle S^{\prime} \mathrm{SZ}$ & $\angle 8^{\prime} 9 \mathrm{I}$ & $8 L^{\circ} 0 \mathrm{I}$ & {$[2 \cdot 9$} & ןeqOL suoqIeวOIp $\kappa_{\mathrm{H}}$ \\
\hline 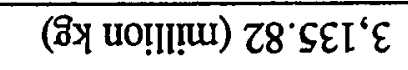 & $9 Z^{\circ} 0 L I^{6} Z$ & IE $L \mathcal{S S}^{\prime} I$ & $9 L^{\circ} S \angle 0^{6} I$ & [ETOL әp!xOUOW UOQIRว \\
\hline 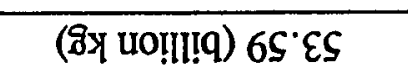 & {$\left[9^{\circ} 8 \varepsilon\right.$} & $\varepsilon \sigma^{\circ} L Z$ & $\varepsilon L^{\prime} 8 \mathrm{I}$ & 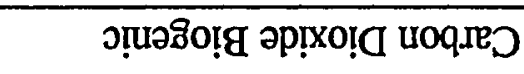 \\
\hline (8у นo!!ा! $L \varepsilon^{\prime} 926^{\prime} Z$ & $06^{\circ} \mathcal{S} \angle 8^{6} I$ & $Z \varsigma^{\circ} Z 0 Z^{\prime} I$ & $09^{\circ} \varepsilon L 9$ & ग!นว৪ిo!g-นoN วp!xo!̣ uoq.reว \\
\hline ozoz & olOZ & 0002 & 066I & SNOISSIWG \&IV \\
\hline \multicolumn{5}{|c|}{ 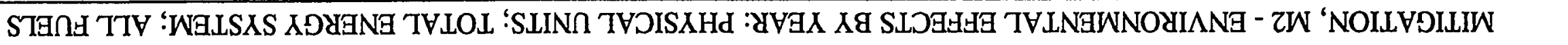 } \\
\hline \multicolumn{5}{|c|}{ व9 H'T\&VI } \\
\hline
\end{tabular}


ऽ9

\begin{tabular}{|c|c|c|c|c|}
\hline 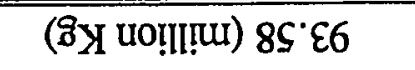 & $89^{\circ} \mathrm{ZS}$ & II'IE & $09^{\circ} \mathfrak{S I}$ & [EาoL Səp!x \\
\hline (89y puresnoul) t0.900'I & $6 L^{\circ}+29$ & $90^{\circ} 88 \varepsilon$ & $66^{\circ} 88 \mathrm{I}$ & วนณчाәW \\
\hline 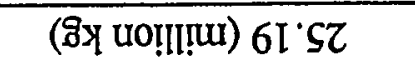 & $08^{\circ} 91$ & $78^{\circ} \mathrm{OI}$ & $I 2 \cdot 9$ & [E]O ${ }_{L}$ suoqrejoIp $\kappa_{H}$ \\
\hline 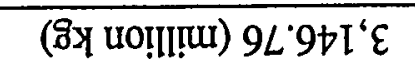 & $20^{\circ} L L I ' Z$ & $9 t^{\cdot}\left[9 \mathcal{S}^{6} I\right.$ & $9 L^{\circ} S L 0^{\prime} I$ & [E7OL әp!xouow uoqreว \\
\hline (8̂X uo!II!q) $6 S^{\circ} \varepsilon S$ & โ9.8E & $\varepsilon 6\llcorner Z$ & $\mathcal{E L} 8 \mathrm{II}$ & ว!ฺวรిం!̣ วp!xo!̣ uoqreว \\
\hline (8ิy uo!I!! $87^{\circ} 86 L^{\prime} Z$ & $\varepsilon S^{\circ} L t 8^{6} I$ & $68^{\circ} \mathcal{S I Z}^{6} \mathrm{I}$ & $09^{\circ} \varepsilon \angle 9$ & 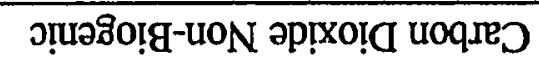 \\
\hline $020 Z$ & OIOZ & $000 Z$ & 066I & SNOISSIWG XIV \\
\hline \multicolumn{5}{|c|}{ 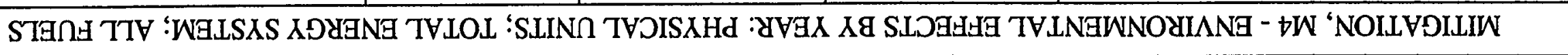 } \\
\hline \multicolumn{5}{|c|}{ H9 HTRVI } \\
\hline
\end{tabular}


Table 6G: Comparison of non-biogenic carbon-dioxide emissions for the baseline and all mitigation scenarios

\begin{tabular}{||l|c|c|}
\hline \multicolumn{2}{|c|}{ NON-BIOGENIC CARBON-DIOXIDE EMISSIONS IN THE YEAR 2020 } \\
\hline DESCRIPTION & Gg & $\begin{array}{c}\text { PERCENTAGE } \\
\text { REDUCTION }\end{array}$ \\
\hline BA, Base case & 3,043 & - \\
\hline M1, Mitigation One & 2,889 & 5.06 \\
\hline M2, Mitigation Two & 2,926 & 3.85 \\
\hline M3, Mitigation Three & 2,906 & 4.52 \\
\hline M4, Mitigation Four & 2,798 & 8.05 \\
\hline
\end{tabular}

\subsubsection{Cost of Emission Abatement}

M1 is a quite costly emission abatement option because the current estimated costs of ethanol production of about US $\$ 100$ cents per litre are much higher than the cost of importing petrol into Uganda which costs 25 US cents per litre. Ethanol production would therefore have to be highly subsidised by Government or petrol highly taxed.

M2 is quite attractive because elimination of traffic congestion results in cost savings. These options imply GHG abatement with economic benefits. It should be noted however the costs and impacts of this option are rather uncertain.

M3 offers an opportunity for GHG abatement and, if properly planned, it gives a potential for economic benefits. Such planning would prioritise rural electrification programmes on the basis of first electrifying the most economically active areas. Over the life of the technology, (e.g. solar photovoltaic or small hydropower plant) the total cost is bound to be, lower than the cost of the avoided fuel (kerosene or diesel).

M4 may be economically attractive in the long run considering that the fossil fuels are imported and hydropower is relatively inexpensive. Another consideration is that since Uganda is endowed with hydropower it is possible that electricity tariffs will get lower as intensive electrification is realised. 


\subsubsection{Contribution of Technology Options for GHG Abatement}

On the basis of the above, the technology options in the non-biomass energy sector for GHG abatement in Uganda are as follows in order of importance: small hydropower development, solar photovoltaic systems, industrial heat generation based on hydroelectricity and ethanol production.

\subsection{Conclusion and Limitations}

Even though the cost analysis has been qualitative, there is significant potential for GHG abatement while contributing to sustainable development in Uganda. To concretise policies and policy implementation programmes that are in line with the analysis above, specific studies could be undertaken to quantify the cost of the options. 


\subsection{REFERENCES}

1. Openshaw, K., 1982. Draft Renewable Energy Sector Report of Uganda.

2. Department of Energy, Ministry of Natural Resources: Unpublished Reports.

3. Department of Energy, Ministry of Natural Resources: Petroleum Sales (1980 - 1996).

4. Ministry of Transport, Communications and Works; Transport Policy and Planning Project, unpublished Acts (1990).

5. Uganda Civil Aviation Authority: Unpublished (1988 - 1994).

6. Uganda Railways Corporation: Unpublished Data on marine and rail transport (1988 and 1990).

7. Department of Fisheries, Ministry of agriculture, Animal Industry and Fisheries: Unpublished Data on fishing vessels (1988 and 1980).

8. Uganda Electricity Board: Unpublished Data on Thermal Generators (1992 - 1993).

9. National Biomass Study, Department of Forestry, Ministry of Natural Resources: Data or Fuelwood (1991) and Publication 1992).

10. Greenhouse Gas Inventory Reference Manual, 1995.

11. Background to the Budget 1995 - 1996: "Economic Performance 1995 - 1996) and prospects for 1996-1992, Ministries of Finance and Ministry of Planning and Economic Development.

12. Census (1991) "Provisional Results of the 1991 Population and Housing Census". Department of Statistical, Ministry of Finance and Economic Planning, Uganda, July 1991.

13. UNDP/World Bank (1980).

14. Byarugaba et al: NEAP Background document on Energy and climate change, National Environment Action Plan Secretariat.

15. Ministry of Natural Resources Power 17 Project document Copdes Nos. ME-06A \& B (R + D Plan Volume II, Priority Projects).

16. Ministry of Natural Resources, Power III, project Code No. ME - 19(N) (R\&D Plan Volume II, Priority Projects). 
17. Uganda Airlines Corporation.

18. Sources and sinks of Greenhouse Gases in Uganda - Republic of Uganda, 1996. 


\subsection{GENERAL CONCLUSIONS AND RECOMMENDATIONS}

Vulnerability and adaptation options assessment was carried out for the sectors of water resources, forestry, crops as well as livestock and rangelands while mitigation options assessment was done for the energy sector. The results of the study are summarized below.

Table 7A below gives a list of the more important impacts while Table 7B gives a list of selected adaptation measures.

Table 7A: Selected Potential Impacts of Climate Change in Uganda

- Crop failure or significantly reduced crop production in some years due to increased drought incidence associated with increased climatic variability.

- Increased hunger and famine due to crop failure caused by drought and/or flooding.

- Increased land degradation due to droughts and floods.

- Destruction or damage to wetlands and estuaries.

- Increased pest infestations such as armyworm, cassava mosaic and other temperature/weather related plant pathogens.

- Higher order impacts including increased costs of production, increased risks, lower profitability, leading to a decrease in food security, reduced exports and a need for more food imports.

- A shift in vegetation zones, particularly in the rangelands and the cattle corridor. In times of drought this will adversely affect both livestock and wildlife.

- Variations in the hydrological cycle will at times reduce the available water for livestock and wildlife.

- Reduced livestock feed because of drought will lead to a reduction in total livestock and hence a reduction of animal protein in the diet, leading to malnutrition in those communities that relies more heavily on the cattle economy.

- Reduction in the bio-diversity in tropical forests, which may result in the loss of important medicinal and gene resources.

- Reduction of the moderating impacts of forecasts on climate. If the forest area shrinks significantly it will mean reduced water catchment areas and hence reduced downstream flow. 
- Loss of regeneration capacity in forests, e.g. when forest cover is lost due to drought and land clearance the natural capacity to grow back will have been lost and entires forest ecosystems will be at risk.

- Reduction of underground water resources, (especially in the Karamoja region) resulting in changed land covers and lack of water for the growth of human settlements.

- Expansion in the areal extent of some disease vectors, increased incidence of climate related diseases including malaria, schiostosomiasis, trypanosomiasis, yellow fever, onchoceroiasis and encephalitis.

\section{Table 7B: Selected adaptation Measures}

\section{Cross-cutting Measures}

- Strengthen Uganda's meteorological services so that they may provide reliable medium to long term advisories with respect to droughts and floods.

- Strengthen the Early Warning Information capacity, especially for food security and short-term climate precision.

- Incorporate climate change and variability information and projections into Uganda's long-term development plans, such as the National Environment Action Plan (NEAP), the Poverty Eradication Action Plan (REAP), and the Decentralization Process.

- Carry out an inventory of existing practices and poise used to adapt to different climates in all line agencies and sectors, so as to begin more detailed identification of adaptation measures for evaluation and adaptation.

- Ensure that the Uganda Disaster Preparedness Committee (UDPC) includes in its work plan long-term hazard reduction related to climate change and climate variability.

Promote awareness of climate variability and change and potential responses alternatives throughout Uganda society.

\section{Adaptation Measures Incremental to Specific Sectoral programmes}

\section{Agriculture}

- Develop better heat- and drought-resistant crop types and seed banks to counteract climate change and/or expand food production in currently marginal areas. 
- Reduce reliance on mono-culture, (e.g. matoke (banana) planting).

- Expand irrigation and increase irrigation efficiency.

\section{Water Resources}

- Renegotiate the Nile Waters Agreement to include climate change response plans on the utilization of the Nile River Waters.

- Both the Uganda Government and communities should begin to adopt contingency planning for both drought and floods, aimed at managing current climate variability especially in the most vulnerable districts.

- Encourage water conservation at all levels of the community using appropriate methods including use of market based systems.

\section{Forests and Ecosystems}

- Review the Uganda FAP to ensure that climate variability and change have been considered. (A general review is already in progress).

- Enhance and strengthen The Uganda Tree See Project to ensure that original biodiversity is protected against climate change and climate variabollty8 so as to guard against irreversible species disappearance.

- Re-examine the current forestry managerial practices and strategies so as to provide a buffer against climate variability (e.g. the feasibility of planting drought-resistant trees in the north-east ranges of the country to accommodate current drought episodes.

- Reduce geographic fragmentation of forests to ensure that forest types can freely migrate in the face of climate change.

- Coordinate with neighbouring countries to plan and manage ecosystems, particularly in light of Uganda's very high level of bio-diversity and its vulnerability to climatic variability and change.

- Encourage off-site bio-diversity protection so as to avoid species extinction.

The following sub-section discusses the mitigation analysis results for the energy sector. 


\section{GHG Mitigation Analysis}

The mitigation options for energy related greenhouse gas emissions in Uganda were analyzed for the period 1990 to 2020 . In the analysis, the base case energy demand and supply situation was presented and using the energy model, Long Range Energy Alternatives Planning (LEAP) and the official base case energy demand forecasts, the GHG emissions over the study period were presented. The LEAP model was further used to analyze the mitigation options identified by the study.

\section{Energy Sector Overview}

95\% of energy consumption in Uganda in 1990 was derived from biomass energy resources. If the biomass resources were to be used on a sustainable basis, this consumption area would effectively not contribute GHG emissions since carbon emitted would be balanced by carbon sequestered during biomass growth. The stainable use of biomass based fuels will be ensured if the following actions are promoted:

- Afforestation

Afforestation/reforestation of hilly areas shall help control soil erosion, protect watersheds and expand the carbon stock.

- Forest Protection and Conservation

The greatest threats to the forestry areas protected by Government have been encroachment for agricultural expansion and fuel wood harvesting. If this encroachment is controlled, the forest resources can be used in a sustainable manner.

The remaining $5 \%$ of energy consumption in 1990, representing $11.28 \mathrm{PJ}$ is accounted for by electricity (1.15PJ) and petroleum products (10.13PJ). Almost all of the electricity is generated from hydropower. Therefore, electricity production and consumption does not contribute to GHG emissions. Due to the great potential for hydropower development, which is relatively cheap by world standards, the situation is bound to remain the same for years to come.

Increased electrification offers an opportunity for GHG mitigation where electricity replaces use of fossil fuels like kerosene for rural lighting, diesel in small scale agrobased industries, and residual/fuel oil in industries. Increased electrification rate based on grid extension can be supplemented by small-scale hydropower development and solar pv systems. 
Almost $80 \%$ of the fossil fuel use is accounted for by road transport. Rational use of energy in the road transport sector, therefore, can significantly contribute to reduction of GHG emissions in Uganda. This would include efficient use of fossil fuels arising from reduction of traffic congestion, proper maintenance of roads and proper maintenance of vehicles. Another option is substitution of petrol by ethanol derived from biomass resources. Such ethanol would be blended with petrol.

\section{Scenarios}

Five scenarios were analyzed: Base case and four mitigation options.

\section{Mitigation 1, (M1)}

Petrol-ethanol blending to a level of $15 \%$ for all petrol by the year 2020 (Ethanol blended with petrol up to a level of $20 \%$ would not require modification of the petrol engine. For this analysis, $15 \%$ blending is selected to ensure operation well within the recommended blending ratio).

\section{Mitigation 2, (M2)}

- Reduction of traffic congestion on all roads by:

- ensuring proper road maintenance;

- improvement of road infrastructure to cater for pedestrians and other non-motorized transport;

- proper vehicle maintenance;

- installation of proper road signals; and

- development and implementation of policies and fiscal incentives to encourage mass public transport as opposed to use of small private cars.

Based on the results of a survey carried out in 1991, the analysis has assumed that reduction of congestion would lead to fuel savings of approximately $5 \%$.

\section{Mitigation 3, (M3)}

Development and implementation of an enhanced rural electrification programme to improve the electrification rate from the current $5 \%$ to $90 \%$ by the year 2020 . This will reduce dependence on kerosene for lighting in the residential sector.

The electrification strategy would be a combination of grid extension, development of small-scale hydropower in areas remote from the national grid and use of solar photovoltaic systems. 


\section{Mitigation 4, (M4)}

Elimination of use of residual/fuel oil in industries by replacement with hgydro-based grid power. Analysis is based on the ideal assumption that complete elimination of residual/fuel oil is realized by the year 2020 .

The results from the analysis are summarized below.

\begin{tabular}{|l|c|c|}
\hline \multicolumn{2}{|c|}{ NON-BIOGENIC CARBON-DIOXIDE EMISSIONS IN THE YEAR 2020 } \\
\hline \multicolumn{1}{|c|}{ DESCCRIPTION } & Gg & PERCENTAGE REDUCTION \\
\hline BA, Base case & 3,043 & \\
\hline M1, Mitigation One & 2,889 & 5.06 \\
\hline M2, Mitigation Two & 2,926 & 3.85 \\
\hline M3, Mitigation Three & 2,906 & 4.52 \\
\hline M4, Mitigation Four & 2,798 & 8.05 \\
\hline
\end{tabular}

Cost of Emission Abatement

$M 1$ is a quite costly emission abatement option because the current estimated costs of ethanol production of about US $\$ 100$ cents per litre are much higher than the cost of importing petrol into Uganda which costs 25 US cents per litre. Ethanol production would therefore have to be highly subsidized by Government or petrol highly taxed.

M2 is quite attractive because elimination of traffic congestion results in cost savings. These options imply GHG abatement with economic benefits. It should be noted however the costs and impacts of this option are rather uncertain.

M3 offers an opportunity for GHG abatement and, if properly planned, it gives a potential for economic benefits. Such planning would priorities rural electrification programmes on the basis of first electrifying the most economically active areas. Over the life of the technology, (e.g. solar photovoltaic or small hydropower plant) the total cost is bound to be, lower than the cost of the avoided fuel (kerosene or diesel).

M4 may be economically attractive in the long run considering that the fossil fuels are imported and hydropower is relatively inexpensive. Another consideration is that since Uganda is endowed with hydropower it is possible that electricity will get lower as intensive electrification is realized.

It should, however, be recognized that the adaptation and mitigation measures identified will have to be consistent with and be integrated with other socio-economic development plans and programmes. Related plans, programmes and opportunities for the other plans and programmes to contribute to reducing greenhouse gas emissions or adaptation to the impacts of climate change will be identified and appropriate processes to achieve integration with the other plans and programmes determined. 